Article

\title{
How Policies Affect the Use of Plant Genetic Resources: The Experience of the CGIAR
}

\author{
Isabel López Noriega ${ }^{1{ }^{*} \text {, }}$ Michael Halewood ${ }^{1}$, Gea Galluzzi ${ }^{2}$, Ronnie Vernooy ${ }^{1}$, \\ Enrico Bertacchini ${ }^{3}$, Devendra Gauchan ${ }^{4}$ and Eric Welch ${ }^{5}$
}

1 Bioversity International, Via dei Tre Denari, 472/a Maccarese, Rome 00057, Italy;

E-Mails: m.halewood@cgiar.org (M.H.); r.vernooy@cgiar.org (R.V.)

2 Bioversity International, Regional Office for the Americas, c/o CIAT, km 17 Recta Cali-Palmira, Cali 6713, Colombia; E-Mail: g.galluzzi@cgiar.org

3 Department of Economics and Statistics, University of Turin, Lungodora Siena 100, Torino 10153, Italy; E-Mail: enrico.bertacchini@unito.it

4 Socioeconomics and Agricultural Research Policy Division, Nepal Agricultural Research Council, Singhadurbar Plaza, Kathmandu P.O. Box 5459, Nepal; E-Mail: devendragauchan@yahoo.co.uk

5 Science, Technology and Environment Policy Lab, Department of Public Administration, University of Illinois at Chicago, MC 278, 412 South Peoria Street, Chicago, IL 60607, USA; E-Mail: ewwelch@uic.edu

* Author to whom correspondence should be addressed; E-Mail: i.lopez@cgiar.org; Tel.: +41-789-079-741; Fax: +39-06-619-796-61.

Received: 5 June 2013; in revised form: 12 July 2013 / Accepted: 18 July 2013 / Published: 19 August 2013

\begin{abstract}
There is growing recognition that sustainable intensification of agricultural production systems and their successful adaptation to changes in climate will depend upon the improved access to, and use of, genetic diversity. This paper analyzes how the collection, use and distribution of plant genetic resources by the Consortium of International Research Centers of the CGIAR are influenced by international and national policies, treaties and agreements. Some concerns exist among CGIAR scientists about continued access to, and distribution of, plant genetic resources. Study findings point to an increasing influence of international and national policies and legal frameworks on the conservation and use of plant genetic resources for food and agriculture (PGRFA) by the CGIAR centers and the dissemination of CGIAR-improved germplasm first to partners in agricultural research organizations and then to final users of new plant varieties developed through research partnerships. This situation may, in the longer term, have a serious impact
\end{abstract}


on the utilization of plant genetic diversity to cope with current and predicted challenges to agricultural production and, in particular, climate change.

Keywords: plant genetic resources; policies; access and benefit-sharing; intellectual property rights; partnerships; technology development and dissemination

\section{Introduction}

Plant genetic resources for food and agriculture (PGRFA) are strategic goods for crop improvement through farmer selection, conventional plant breeding and modern biotechnological techniques. Crop improvement enables agriculture adaptation to biotic and environmental changes as well as the development of new foods and new uses. Supportive policies and laws could create an enabling environment for the use of plant genetic resources in crop improvement, and for the adoption of improved plant varieties by farmers. The International Treaty on Plant Genetic Resources for Food and Agriculture (ITPGRFA) stresses the commitment of its member countries to put in place policies and legal frameworks that facilitate the conservation, exchange and sustainable use of such resources, but, to date, detailed discussion of the actual content of such policies and legal frameworks has been sparse [1].

The Consortium of International Research Centers of the CGIAR is a global partnership that unites 15 centers engaged in agricultural research, working in collaboration with partner organizations, including national and regional research institutes, civil society organizations, academia, and the private sector. The centers of the CGIAR have new opportunities to coordinate international efforts to conserve, improve and use plant genetic resources. Positioned at the nexus of national agricultural research organizations (NAROs), international and national research institutes, and private sector and civil society organizations, including farmer associations, they are uniquely situated to contribute to crop improvement in view of current and predicted challenges such as climate change adaptation, steady population increase and globalization of food crop markets. CGIAR centers' experience with policy, partnerships, germplasm diffusion and use strategies are likely relevant to a broad range of organizations who work with plant genetic resources and who seek effective approaches to address these challenges through an enhanced conservation and use of plant genetic resources.

To date, there has not been a collective stock-taking of how the CGIAR centers have modified the management and use of plant genetic resources in response to evolving policies and legal frameworks. In the context and with the support of the CGIAR Programme on Climate Change, Agricultural and Food Security (CCAFS), the authors aimed to address this "gap" through an analysis of how the collection, use and distribution of plant genetic resources for food and agriculture by the CGIAR centers may be changing in response to the changes in policies. The key question this paper addresses is: What policies support or impede the efforts of the CGIAR centers and their partners to access, use and distribute plant genetic resources? By answering this question, this paper aims to provide useful insights for the design and evaluation of policies that effectively support the use of crop diversity for dealing with current and future challenges to agricultural production. Initially, this study paid particular attention to climate change as a driver of transformation of CGIAR centers' activities on conservation and improvement of PGRFA, and analyzed the influence of policies and legal 
frameworks on such activities in the light of the centers' and their partners' needs to adapt to climate change. Our findings indicate that climate change has not radically changed breeding priorities and approaches in the CGIAR, and that existing policies do not (yet) have a differential impact on the centers' activities and technologies related to climate change adaptation.

The paper starts with an explanation of how the CGIAR gene banks and breeding programs operate, with a particular attention to recent changes in the centers' approach to technology generation and dissemination. We then describe how certain policies affect the centers' conservation and use of plant genetic resources, followed by a synthesis of the findings and an analysis of their significance.

\section{Analytical Framework}

For practical reasons, we conceptually divide our analysis according to the patterns of germplasm flow into, within and out of the CGIAR centers as represented in a schematic form in Figure 1. For the purposes of our analysis, we differentiate between the experiences of gene banks acquiring, analyzing, conserving and distributing germplasm and the experiences of the breeders and breeding programs.

Figure 1. Germplasm flows in and out of the CGIAR. Source: the authors.

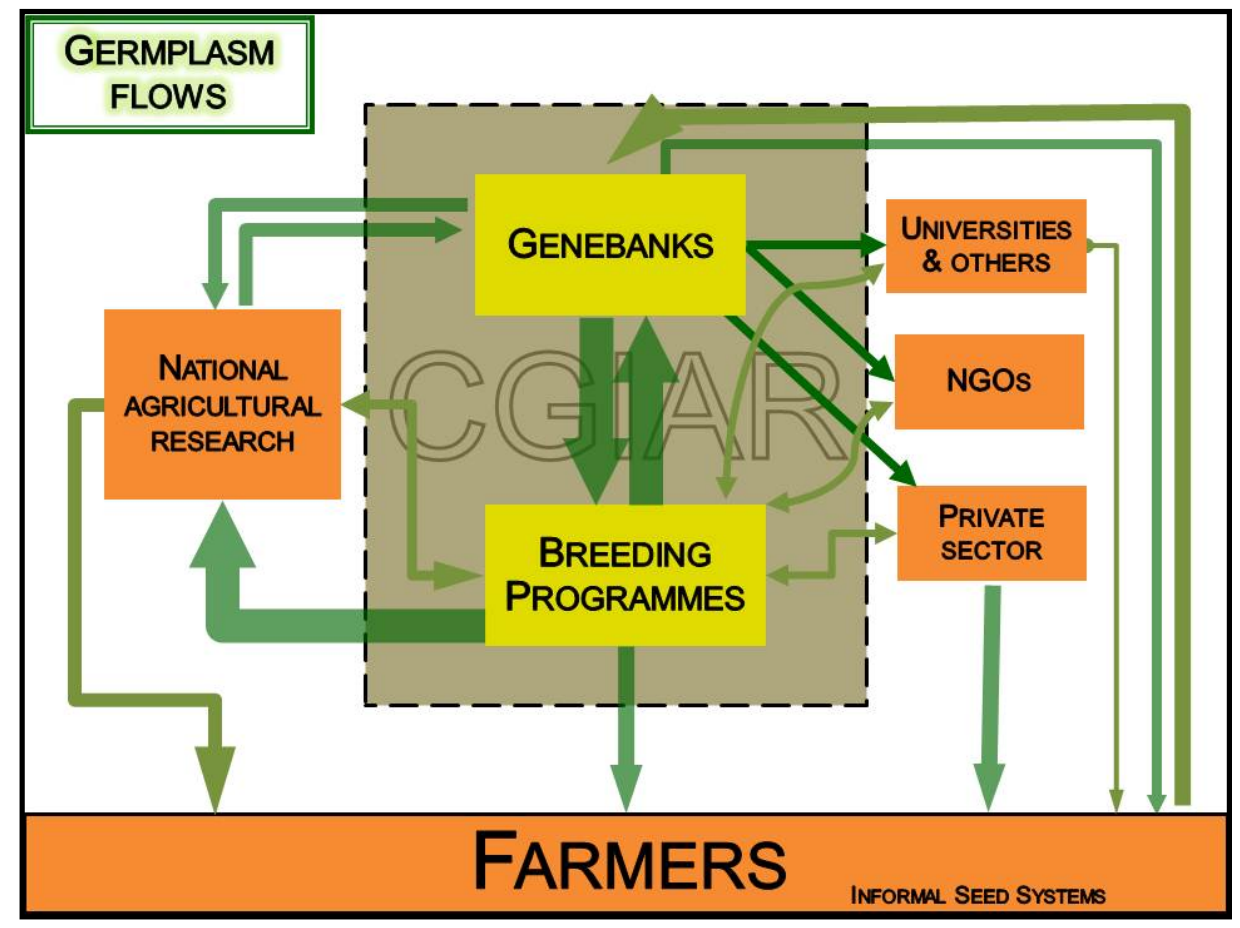

The CGIAR centers operate in a wider, external institutional context that includes international and national policies and laws (for example, those concerning agricultural biodiversity, plant genetic resources, seed systems, trade, technology and intellectual property rights), funding priorities, capacities and rules of donor agencies and programming agendas of development agencies.

Our study draws on a combination of two types of models, known as knowledge systems and social actor approaches [2]. According to the first model, we analyze the institutional and organizational structures and mechanisms through which knowledge and germplasm are generated and disseminated among the actors at various levels and locations. This assessment is then combined with an analysis of how the key social actors - in this case, gene bank managers, breeders, intellectual property right (IPR) 
specialists, extension agents, NGO staff and farmers-actively take part in, and make decisions about, the use, management and conservation of germplasm.

\section{Methodology}

This study is based on data and information gathered from three main sources. Firstly, to provide background for the study, the project team conducted an extensive review of both the academic and grey literatures to establish a framework for the analysis and to identify specific issues for further in-depth exploration. Four key topics were identified: (1) strategies and channels for the dissemination of improved germplasm; (2) factors influencing the uptake of crop technologies; (3) impacts of intellectual property rights and access and benefit-sharing policies on agricultural research; and (4) the CGIAR centers' collaborations with the private sector. The literature was also referenced after the completion of the primary data collection.

Secondly, the research team collected and analyzed data on germplasm acquisition and distribution by the CGIAR gene banks and breeding programs. Analysis provided an overview of the extent and coverage of CGIAR-facilitated germplasm flows. Finally, the team conducted 70 personal interviews with scientists who are directly involved in germplasm research and management in eight CGIAR centers [3]. Interviewees included 29 breeders, 8 policy and legal specialists, 8 gene bank managers and 25 other scientists from natural resource management, geographic information systems, and the social sciences.

\section{Operations of the CGIAR Gene Banks and Breeding Programmes in the Last Decade}

In order to understand how policies affect the work of the CGIAR centers, we will first describe how the centers' gene banks and breeding programs operate. The work of the centers has not remained static since their establishment, but it has evolved to respond and adapt to the changing needs and priorities of their national partners, new roles played by emerging actors and gaps left by traditional institutions which are progressively vanishing, pressures of international donors and evolving policy and legal frameworks. In the following sections, in addition to providing an overall picture of how the centers work, we try to highlight the centers' operative changes that have either increased their exposure to evolving policy and legal frameworks or resulted from their efforts to respond to such policies and legal frameworks. One example of the former is the increasing collaboration between the centers and the private sector, in some cases through research consortia. An example of the latter is the centers' progressive involvement in the dissemination of improved plant varieties to farmers and the development and implementation of locally adapted seed laws. Later in the paper we will refer back to the operative changes presented in this section to analyze the increased influence of certain policies on the centers' capacities to use and disseminate germplasm.

\subsection{CGIAR Gene Banks}

\subsubsection{Operation of the Gene Banks}

Most of the international ex situ collections of plant genetic resources currently conserved by 11 of the CGIAR gene banks began as working collections used by teams of scientists both inside and 
outside the CGIAR. Over time, the centers accepted responsibility for maintaining the collections on behalf of the international community, subject to internationally recognized standards. They agreed to provide global-facilitated access to these collections for the purposes of agricultural research and development, conservation and breeding. The gene banks redistribute samples of the materials they received (and keep as accessions) to countries all over the world. The CGIAR collections currently include 693,766 accessions of PGRFA, originally collected from 195 countries. Between 1979 and 2009, the centers' gene banks distributed materials to 178 countries [4]. Figure 2 shows the range of countries that have received samples of material through the CGIAR gene banks over this period.

Figure 2. Number of samples sent to countries by CGIAR gene banks (1979-2009) [5]. Source: SINGER [4].

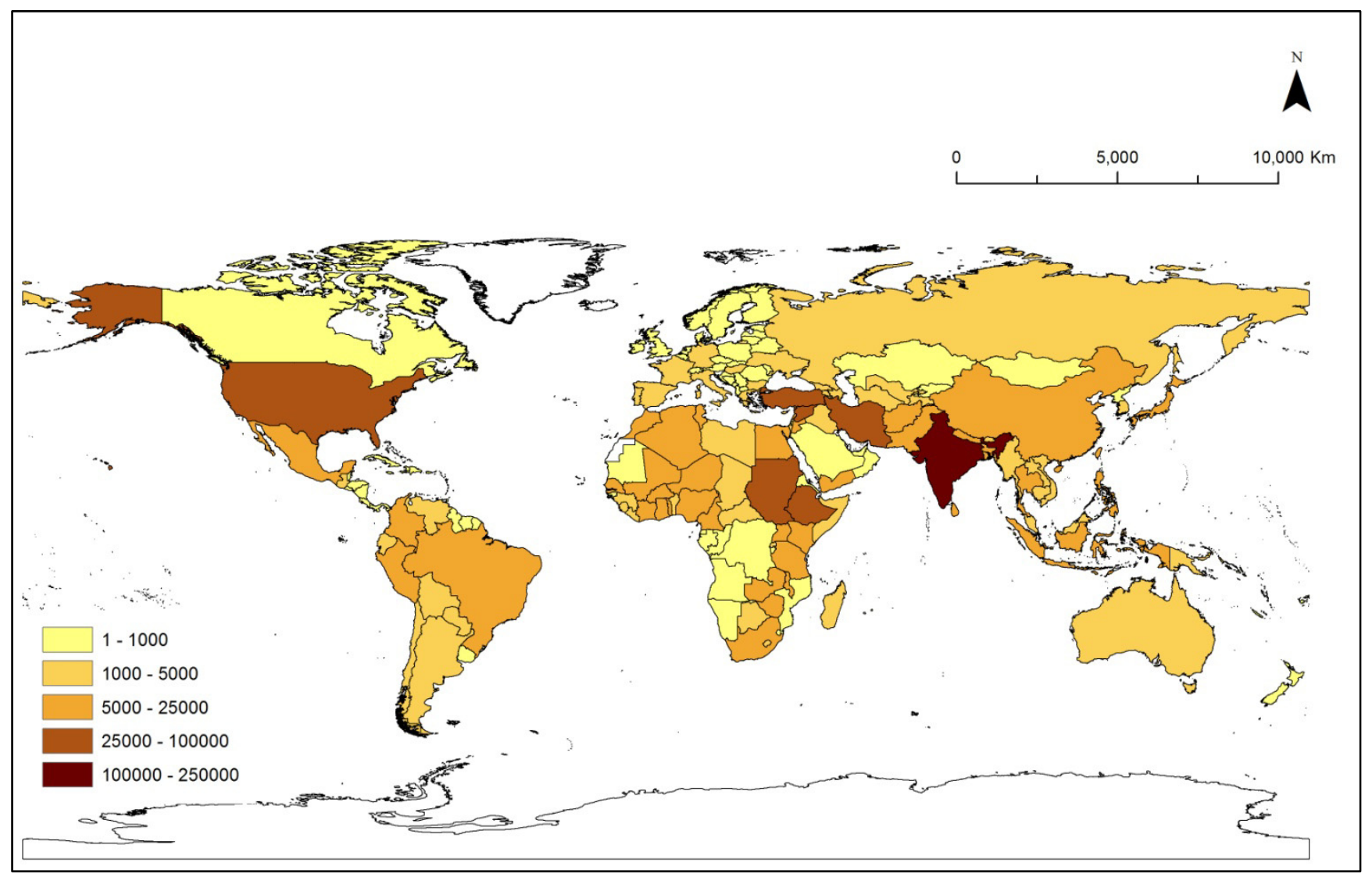

The CGIAR centers have traditionally acquired materials either from other pre-existing ex situ collections or from missions to collect materials from in situ conditions. Collecting missions are usually organized in cooperation with national partners. Subsamples of the materials collected are deposited with the national partners (in the national gene bank if there is one) with the understanding that copies of the germplasm collected will be forwarded to the centers.

Over the years, the numbers of new, unique acquisitions have dropped considerably (a trend that began around 1992), except for a slight increase in the most recent period. This atypical increase is due to the efforts of an international "regeneration" project supported by the Global Crop Diversity Trust (GCDT) and the Bill and Melinda Gates Foundation. Between 2008 and 2010 (inclusive), 20 developing countries sent samples of over 14,500 regenerated accessions to various CGIAR gene 
banks [6]. Figure 3 shows the trend line in the annual number of unique acquisitions between 1979 and 2009.

Figure 3. Trend in annual acquisitions of unique accessions entering the CGIAR collections from 1979 to 2009. Source: SINGER [4].

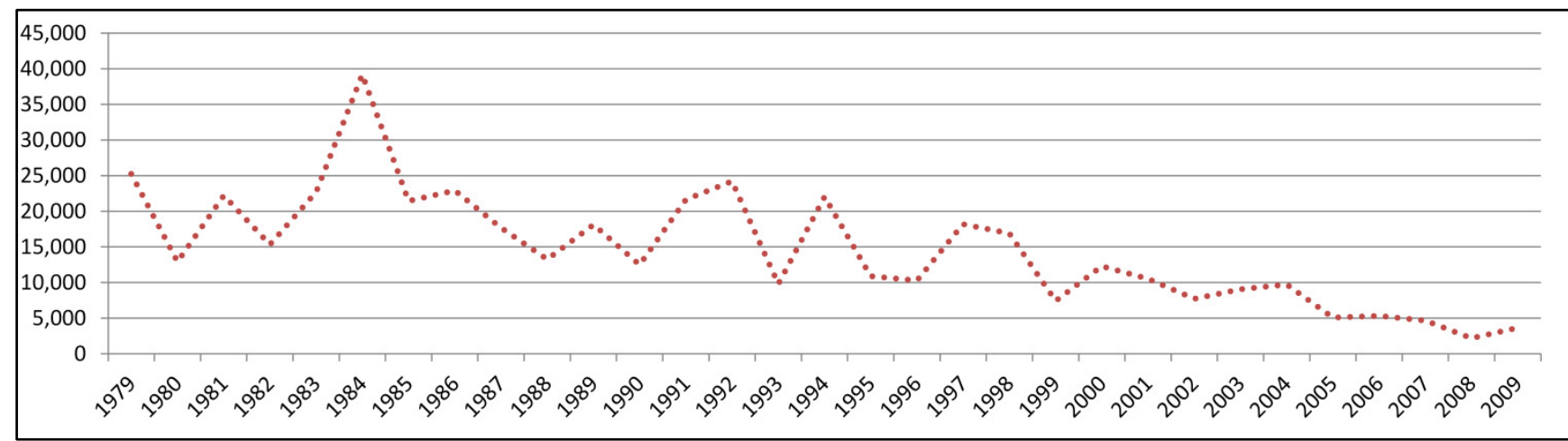

The CGIAR centers generally make materials available to anyone — organization or individual — who requests it for the allowed purposes, for free or for a minimal fee. They may decline to provide materials if they do not have sufficient samples in stock. The CGIAR gene banks, together with the geneb anks of the National Plant Germplasm System of the United States are the major providers of plant germplasm internationally. Most of the materials the centers' gene banks distribute go to public sector research and breeding organizations, particularly in countries in the developing world [7]. Among the largest users of the CGIAR gene banks are the CGIAR breeding programs.

Figures 4 and 5 show the distribution of gene bank accessions between 1984 and 2010 in terms of their origin and destinations (developing or developed [8] countries). Developing countries are consistently stronger donors of material than developed countries, and also the main recipients of CGIAR-conserved germplasm.

Figure 4. Total number of samples distributed from 1984 to 2009, by CGIAR gene banks, of materials originally sourced from developed or developing countries. Source: SINGER [4].

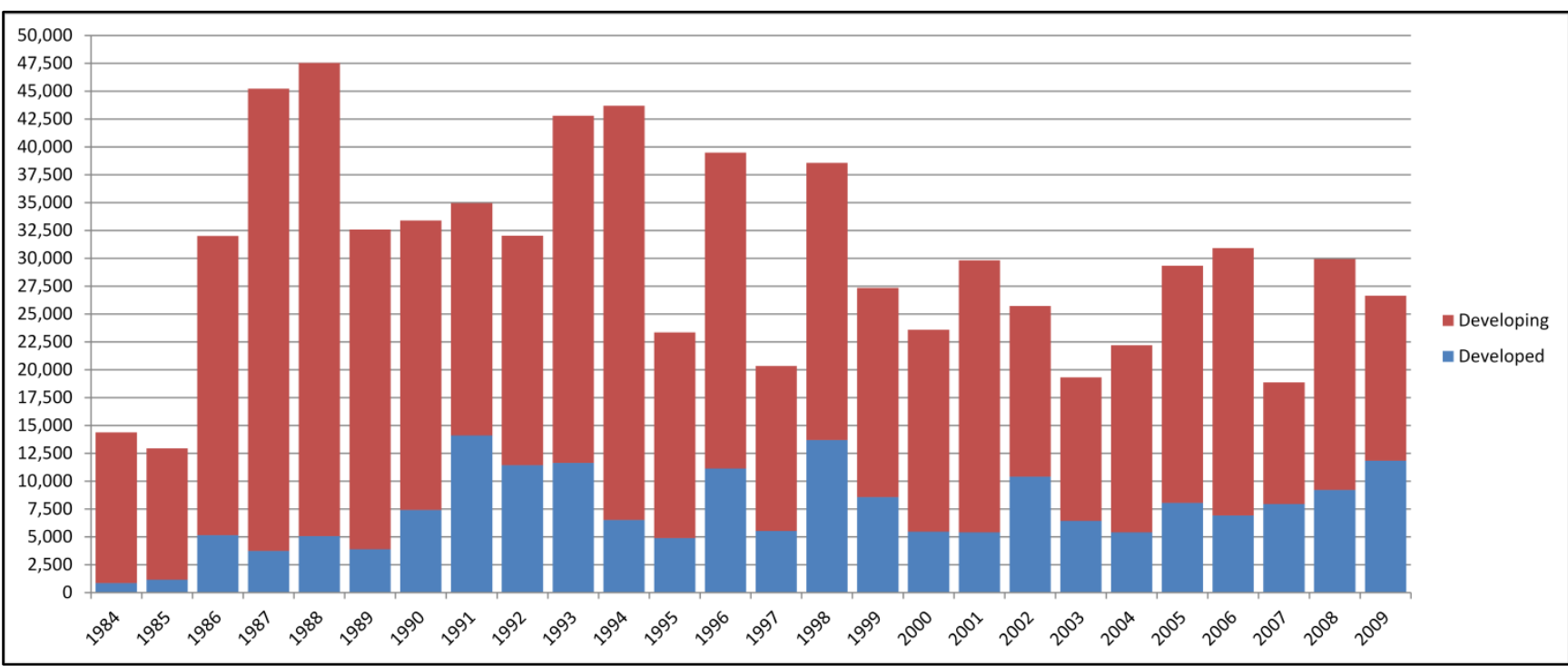


Figure 5. Number of samples distributed by CGIAR gene banks to developed and developing countries from 1984 to 2009. Source: SINGER [4].

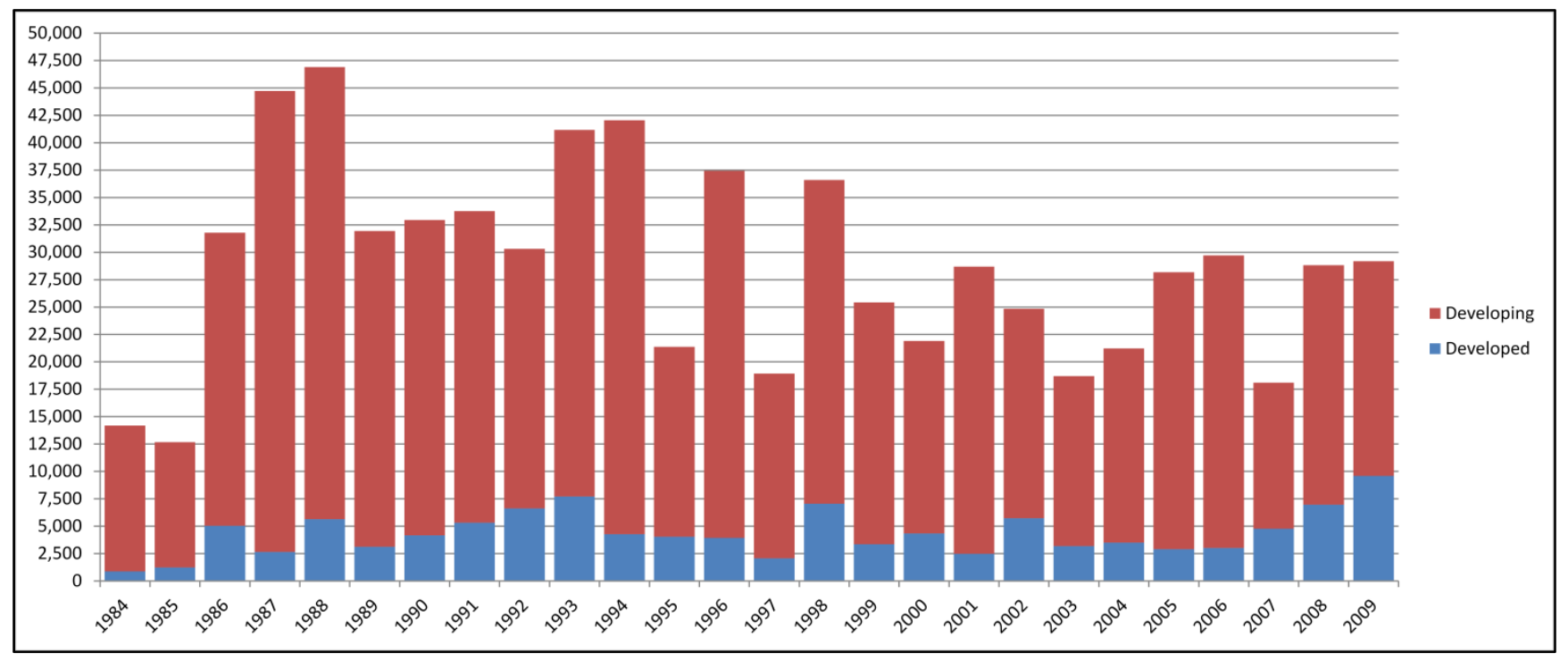

The levels of distribution of samples from the gene banks have experienced a slight downward trend over the last 15 years (since 1998). The gene bank managers attribute this decrease mainly to (1) the increased ability of gene banks to target responses to requests; and (2) the ability of some requestors to make more targeted requests. This tendency towards more focused requests has also been observed in some national genebanks, and associated to users' increased knowledge about specific accessions gained through personal experience and by examining evaluation and characterization data [9]. The centers' ability to target responses to germplasm requests has increased thanks to the development of tools that allow gene bank managers and agricultural researchers worldwide to screen large plant genetic resource collections more rapidly and accurately than was previously possible using traditional methods. The tool Focused Identification of Germplasm Strategy (FIGS), developed by the International Centre for Agricultural Research in the Dry Areas (ICARDA), is an important step in this direction [10].

\subsubsection{The Status of CGIAR Gene Banks in an Evolving International System of PGRFA Conservation,} Exchange and Use

The rights and responsibilities of the CGIAR centers concerning the ex situ collections have gradually been formalized through international legal agreements. In 1994, the centers hosting international collections-12 at the time-signed agreements with the Food and Agriculture Organization of the United Nations (FAO) to hold designated germplasm in trust for the benefit of the international community and to make samples of the designated germplasm and related information available directly to users or through FAO, for the purpose of scientific research, plant breeding or genetic resource conservation, without restriction [11]. The centers developed their own guidelines stating that they would designate germplasm as being "in-trust", that they had the legal right to make it globally available and that they intended to make long-term conservation commitments. The centers adopted a material transfer agreement (MTA) for distributing in-trust materials, stating that in-trust materials could be made available for direct use by farmers. Under this agreement, the centers 
subjected themselves to the overall policy guidance of the FAO's Commission on Genetic Resources for Food and Agriculture (CGRFA) as far as issues related to the management of the in-trust materials were concerned. The in-trust agreements were a stop-gap measure meant to clarify the legal status of the collections until the negotiations of the International Treaty on Plant Genetic Resources for Food and Agriculture (ITPGRFA) were concluded. In 2006, 11 centers hosting collections signed agreements with the governing body of the treaty placing their in-trust collections under the purview of the Treaty [12]. Thus, the centers subjected themselves to the overall policy guidance of the governing body with respect to the management of their collections and undertook to use the treaty's Standard Material Transfer Agreement (SMTA) when distributing materials they held "in trust" or that incorporated materials from the multilateral system. As a result of the way things have developed, the materials that the centres actually distribute under the SMTA includes materials designated as "in trust" under the 1994 agreements, materials the centers received under the SMTA, and materials they received under some other instrument with permission to redistribute that material by using the SMTA [13].

\subsection{CGIAR Breeding Programs}

\subsubsection{Operation of the Breeding Programs}

The contribution of international agricultural research — particularly, the CGIAR centers' efforts to improve crops through yield and productivity increases - has been well documented in a number of studies [14-16]. The diffusion of modern varieties that farmers in developing countries are growing nowadays to cope with biotic and abiotic stresses has depended to a large degree on the germplasm coming out of the CGIAR centers, particularly for some crops like rice, maize and wheat. Countries all over the world have been strongly dependent on receiving germplasm from the CGIAR centers for the development of commercial varieties [17]. This dependency has been demonstrated for specific crops; see, for example, a study on beans in Latin America [18], and in various national and regional case studies, including Mexico [19], Turkey [20], Ethiopia [21], West and Central Africa [22], Zimbabwe [23], India [24], Nepal [25] and south Asia [26]. Figure 6 shows the global distribution of all CGIAR breeding materials for 2009. Top recipients, with over 5000 samples, were India, Argentina and Mexico.

CGIAR breeding programs follow different operational strategies. We present the most salient ones in the following paragraphs. The choices of breeding methodology and partnerships are a function of: (1) the crop, its breeding biology and history of improvement; and (2) the target region or countries, their stages of agricultural development and their socioeconomic characteristics. 
Figure 6. Countries classified based on the number of transfers of germplasm from CGIAR breeding programs in 2009 [27]. Source: SINGER [4].

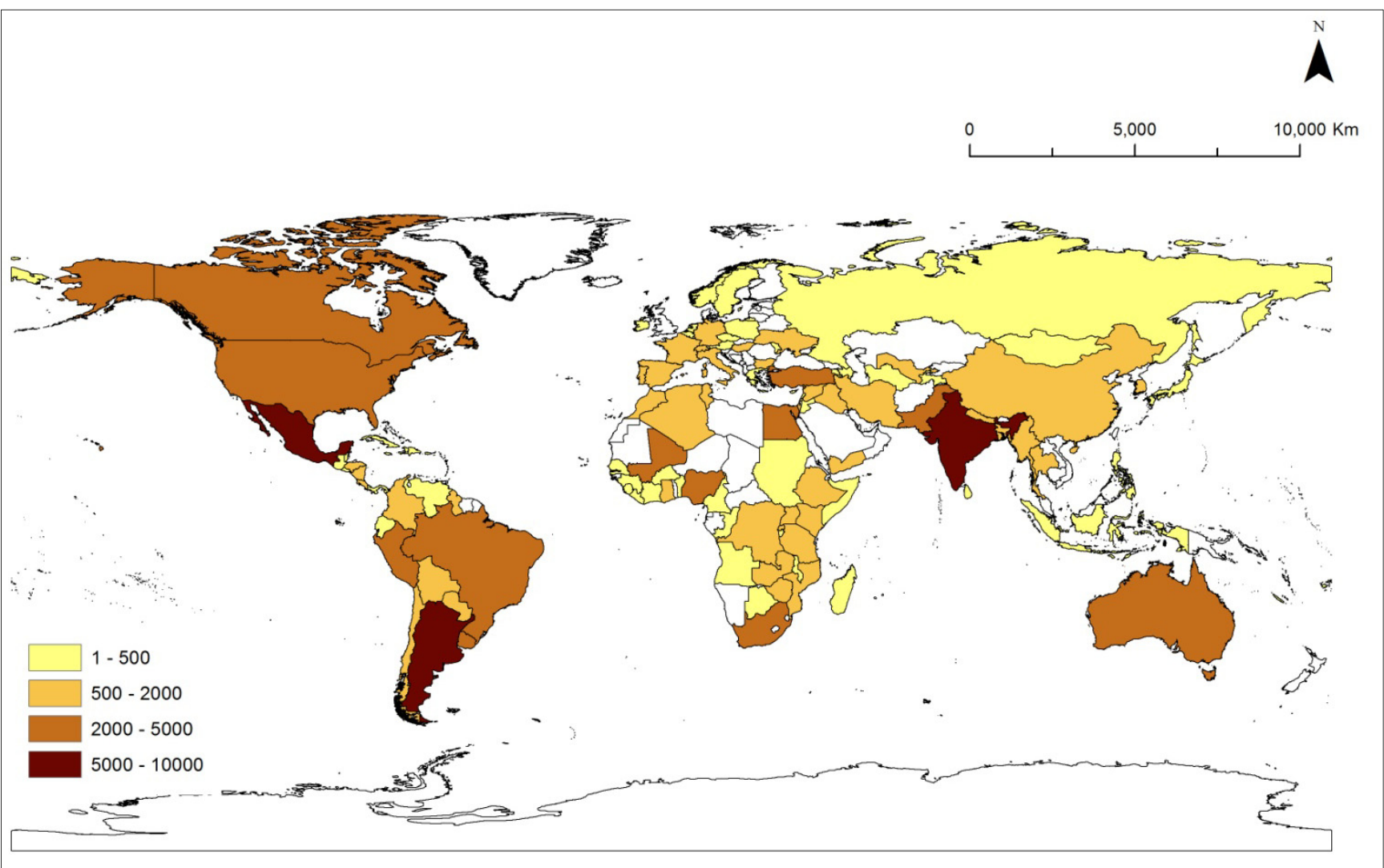

\subsubsection{International Evaluation and Improvement Networks}

For wheat at the International Maize and Wheat Improvement Center (CIMMYT, according to the Spanish acronym) and rice at the International Rice Research Institute (IRRI), much of the exchange and testing of germplasm and information has taken place through long-standing networks of international nurseries (the nursery model has been used since 1970). The International Wheat Improvement Network connects breeders within CIMMYT's wheat program to a global network of wheat research cooperators, who evaluate wheat, triticale and barley breeding lines in diverse nurseries located in specific agro-ecological environments. Data from the evaluation trials are returned to CIMMYT, catalogued, analyzed and made available to the global wheat improvement community [28]. The International Network for the Genetic Evaluation of Rice, which was established in 1975 and hosted by IRRI, is a system of specialized rice nurseries that provides a vehicle for exchanging as well as evaluating advanced rice germplasm. The role of the international nurseries has remained the same over the years. However, the scope and coverage of the nurseries have grown and become more complex and sophisticated over the decades. Diverse entries, from segregating to advanced lines, are being provided to different sites according to specific requests and the needs of their local breeding programs. The role of such networks in the development of new wheat and rice varieties and the economic and social impact of such varieties have been significant [17,29].

Other centers have also adopted and supported the model of a nurseries network for their crops. For example, the Bean Regional Nursery for Low Fertility Adaptation identifies and evaluates promising 
germplasm from a number of African countries under the program, Bean Improvement for Low Fertility Soils in Africa of the International Centre for Tropical Agriculture (CIAT) [30].

\subsubsection{Decentralized Breeding in Collaboration with NAROs}

The centers send elite lines to national collaborators, often in the context of collaborative germplasm improvement projects that deal with particular production challenges. The centers' improved germplasm is then incorporated into locally adapted varieties by national partners, leading ultimately, if all goes well, to newly released varieties. Alternatively, the centers can send well-advanced lines to national programs, which select the most useful ones from the populations provided. The International Potato Center (CIP), the International Centre for Agricultural Research in the Dry Areas (ICARDA), the International Institute of Tropical Agriculture (IITA), the International Maize and Wheat Improvement Center (CIMMYT) (maize-breeding programs) and the International Crop Research Institute for the Semi-Arid Tropics (ICRISAT) (cooperation with public organizations in both Asia and Africa on non-hybrid breeding) make use of this decentralized breeding approach. Usually, this kind of research is organized and undertaken through major regional hubs where the centers have offices. For example, in the case of CIMMYT, the four large regions are Meso-America, South America, Asia (India, Nepal and China) and Africa (Kenya, Zimbabwe and Ethiopia). IITA research priorities are defined based upon three sub-regions: eastern Africa, western Africa and southern Africa. NAROs are the main partners in these collaborative breeding efforts, although the CGIAR centers also work with NGOs, universities and private institutions.

In this decentralized model, contrary to what usually happens in the international nursery model, germplasm transfer is often accompanied by a technology package as well as by capacity-building activities depending on the partners' needs and capacities. While assistance to some countries is limited to a number of precise activities, other countries require a more comprehensive package. For example, some partners can cross, test, and select adapted germplasm from parental lines and segregating materials provided by the CGIAR centers, but others require nearly finished varieties. As part of capacity building in plant breeding, centers provide various training opportunities to national breeders, from visits to centers' experimental stations to up to two years' stays in the centers' breeding programs.

In their collaborative breeding projects with NAROs, some of the CGIAR centers have gained experience with comprehensive forms of participation. These experiences include participatory plant breeding (PPB), participatory variety selection (PVS) and the organization of "open house" and farmer field days. PPB involves farmers in the decision-making process about breeding priorities and strategies; PVS involves farmers in the evaluation of materials, sometimes from early on (F2 and F3) but, more regularly, in the final stages of the breeding process. PVS that is used in the early evaluation stages allows for the selection and further development of particular farmer-preferred traits. Open house and farmers' field days are usually one-day events during which collections of experimental materials on station or in farmer's fields can be freely visited for on-site evaluation (sometimes including culinary tasting as well). From 1997 until recently, PPB and PVS were championed by the CGIAR System-wide Program on Participatory Research and Gender Analysis, which was convened by CIAT and co-sponsored by CIMYYT, ICARDA and IRRI. For a number of years, these four centers, plus ICRISAT, Africa Rice Center (previously West Africa Rice Development Association-WARDA) 
and CIP, piloted participatory crop improvement in a number of projects, some of them in close collaboration with NAROs and NGOs [31]. The program ended in 2011 [32].

At present, participatory plant breeding only exists as a sub-program at one of the centers, ICARDA, and is housed within its participatory research program [33]. ICARDA has extended its original PPB work piloted on barley in Morocco, Syria and Tunisia to other countries and other crops in North Africa and the Middle East. In 2010, for example, ICARDA and its national partners started an innovative breeding program in four pilot zones of Eritrea. Farmers, researchers and extension staff jointly evaluated a wide range of crop varieties of barley, wheat, lentil, fava bean and chickpea, both indigenous and introduced, to select promising ones for crop improvement. To accelerate the dissemination of new varieties, a farmer seed co-operative was established in one of the zones. A group of pilot farmers was provided with "nucleus" seed of new varieties developed by the project, together with training on seed production, quality control and storage [34]. ICARDA has used this participatory approach to set up village-based seed production units in several countries, including Jordan [35].

Participatory variety selection (used in different stages) has gained ground in the CGIAR and is practiced in a number of programs and projects carried out by CIAT, CIP, ICRISAT and IRRI. CIP carries out PPB and PVS work through national partner organizations [36] and regional networks, such as INIA in Peru and the National Crops Research Institute in Uganda [37].

IRRI, which piloted PPB in East India in 1997, at present uses PVS to pay attention to end-user needs, including the development and strengthening of seed production systems [38]. Examples are the IRRI-Japan Submergence project for Southeast Asia [39] and the Consortium for an Unfavourable Rice Environment (CURE) [40]. CURE uses a partnership-building approach and combines research and extension, representing a relatively new direction for IRRI. In Central and West Africa, ICRISAT uses PVS in some projects-for example, on groundnuts [41,42].

\subsubsection{Hybrid Research Consortia}

In the hybrid consortium model, private companies use elite hybrid parents from the CGIAR centers to develop hybrids, register them and multiply, certify and sell seed. The companies assume responsibility for crossing the parents and for registering and marketing the varieties. The centers take advantage of the companies' capacity to maintain and cross the parental lines and multiply and distribute hybrid seed. The CGIAR centers draw on their strengths as upstream breeders with access and capacity to identify and introduce useful traits from the genetic diversity of the crops concerned. The role of centers in promoting and supporting the adoption of varieties developed by consortium members is limited. This distribution of responsibility between the two partners - upstream development of parental lines by CGIAR breeders and downstream crossing, maintenance and marketing by private companies - is possible as a result of the high technical capacity of the companies involved and the supportive policy environments in which they operate. For example, in India, variety registration is mandatory for all crop varieties but seed certification is not obligatory for the private sector. Most private seed is sold as "truthfully labeled", requiring the name of the variety and minimum germination and purity standards $[43,44]$. The companies, which generally have more resources than do public sector actors to test and register varieties quickly, are further supported by this 
flexible treatment in national seed laws to get the technologies tested, approved and made available to the market more quickly and more cheaply.

At present, CIMMYT, ICRISAT and IRRI are engaged in hybrid-technology development in maize, pearl millet, sorghum, pigeon peas and rice. At ICRISAT and IRRI, the delivery of improved hybrid lines takes place through the consortia, mostly to private sector companies including those from developed countries. ICRISAT shares its parental lines through the Sorghum, Pearl Millet, and Pigeonpea Hybrid Parents Research Consortia, which were established in 2000 and 2004 and are predominantly active in India. Members of the consortia pay an annual fee in order to receive information and get access and use of ICRISAT's improved lines. ICRISAT's parental lines remain in the public domain and are available to public sector institutions for free at all stages of development [45]. However, NAROs generally do not ask for ICRISAT materials because they do not have the capacity to maintain and cross the parental lines or to multiply and supply hybrid seed to users. Advisory committees (comprised of members from private seed companies and ICRISAT) provide guidance and advice for the consortia's research and development activities. The Hybrid Rice Development Consortium, which was established by IRRI in 2008, uses a similar approach but with an international scope.

Apart from these major models, the CGIAR centers also transfer improved germplasm in response to individual requests, which are not necessarily part of standing partnerships nor associated with a particular project. Information about materials that are available upon request is shared through annual, online catalogues and through e-mail lists. Some programs, such as those on lentil and grasspea at ICARDA and those on chickpea at ICRISAT, regularly organize open-door sessions where scientists from all over the region are invited to visit the CGIAR Centre and request promising lines.

\subsubsection{Technology Generation and Dissemination Practices}

Different perspectives have been adopted to conceptualize the processes of technology development and diffusion [46,47]. In the field of agricultural technology development, including crop improvement, models tend to be divided into two groups. The first includes those models that respond to a classic, linear and functionalistic approach where innovations are seen to move progressively from advanced agricultural research institutions, to national agricultural systems, to national extension systems and, finally, to farmers. The second group includes models that do not assume that innovation systems function smoothly in a top-down and linear manner. Rather, they focus on how different actors make use of different sources of information, relationships and technologies to actively construct (or hinder) the process of innovation, including farmers, community organizations and non-government organizations (NGOs) [48,49]. Traditionally, the work of the CGIAR centers has responded to the first model, and only recently the second model has started to inspire new approaches in the CGIAR operations. In this section, we will explain why and how this shift has taken place.

In general, the CGIAR centers have not been called on to manage the dissemination of improved germplasm to those who would grow and market such varieties. Their work was supposed to end with the delivery of improved lines to national (usually public sector) partners, who would then typically cross them with locally adapted materials, or select the best-suited lines, and release, multiply and distribute them. In this traditional model, the CGIAR centers, in collaboration with national research institutions, have been seen as the sole source of technology. The centers, as technology originators, 
have historically depended on intermediaries for the distribution of new technologies [50]. However, the criticism has been made that the experiences, knowledge, interests and resources of germplasm end-users (men and women farmers) are often overlooked in the traditional model, because the end-users have been considered passive users of the technologies [46].

Many assessments of the adoption and impact of CGIAR breeding activities have been conducted. Many of them report relatively high levels of uptake of modern varieties developed with CGIAR germplasm. However, these results need to be interpreted with caution. Some of the studies are biased by the fact that they only cover regions where a particular crop is most important or areas that have profited from substantial technology promotion, often through the project(s) that is/are sponsoring the study, which can easily lead to over-estimation. Another shortcoming is that the nature of "adoption" in these assessments has rarely been specified, making it unclear what proportions of the farmers' fields are planted with the new varieties [51]. In contrast, a number of studies reported low adoption rates of CGIAR material, particularly in Africa, as compared to Asia [52,53]. In these cases, the traditional operational strategies of the CGIAR centers and their partners have experienced serious shortcomings in delivering improved varieties to farmers.

The top-down and linear approach described earlier has undergone some changes in the last decade for a number of reasons. First, our understanding of the processes of technology development and diffusion has evolved [54]. This understanding has led to different practices and approaches being introduced, piloted and refined by innovating scientists within the centers. Currently, technology diffusion is seen by many as a (more) complex and dynamic process, determined by many factors and actors, that may follow different pathways and uptake channels. In these alternative approaches, technology generation and technology dissemination cannot be completely separated-the way technology is developed can very much influence its dissemination and adoption. In addition, the institutional contexts in which research takes place will influence which actors will be involved or exposed to the new technology in the diffusion phase [55].

Second, the CGIAR centers have progressively internalized the need to document and analyze the impact (planned, unplanned, and undesired) of their work, partially as a result of donor pressure to demonstrate clear development outcomes of CGIAR research activities. Donors are demanding increasingly that farmers are provided with tangible, measurable development results, including an increased capacity to adapt production systems to climate change. The newly adopted CGIAR Strategic Results Framework [56] with its commitment to "managing for results" underscores the centers' commitment to reform their work along these lines.

Perceived urgency brought about by climate change has partly contributed to an increased attention to dissemination and adoption within the CGIAR. The rapid and efficient transfer of potentially adapted material to vulnerable areas is increasingly recognized as an essential element of research and development under climate change.

As a result of all these factors, the CGIAR centers have made efforts to define and integrate, from the very beginning, a product-delivery strategy as part of their research agenda. This new approach has involved a wide range of actions, from developing alternative schemes of variety release and distribution, to creating innovative partnerships for germplasm improvement and dissemination. Box 1 provides a few examples of such actions from various CGIAR centers. 
Box 1. Examples of CGIAR centers' activities to increase dissemination and adoption of improved germplasm.

\section{Reinforcing Seed Systems for Better Dissemination of Improved Germplasm}

ICRISAT has dedicated substantial efforts to develop more sustainable seed multiplication and supply systems for staple crops, including "minor" dryland species of relevance for climate-change adaptation [57], especially in cases where public channels have failed to deliver ICRISAT's improved material to farmers. In India, ICRISAT and its partners have developed a method for self-sufficient reproduction of good quality and true-to-type seed by farmers (known as PDKV, the initials of the name of the researchers who developed it, Drs. Panjabrao, Deshmukh, Krishi and Vidyapeeth) [58]. CIP is involved in improving seed systems in the Andes. Depending on the context and local needs, CIP specialists opt for strengthening formal, informal or mixed seed systems [59]. They have considerable experience in working with producer groups and NGOs in seed multiplication, and the seed is certified through alternative schemes, such as quality-declared seed, which was developed by the FAO. ICARDA is unique among the CGIAR centers in having, since 1985, an entire Seed Unit dedicated to supporting seed production and dissemination by national partners. The unit assists in the development of national seed programs in the region by providing training and technical advice, while also supporting breeding activities based at ICARDA's headquarters. One of the Seed Unit's traditional avenues of research revolves around the informal seed sector, given its importance for many of ICARDA's mandate crops and regions of work [60].

\section{Consortia of Public and Private Actors for a More Effective System of Technology Development and Delivery}

CIMMYT's MasAgro [61] project in Mexico supports small and medium seed company development in areas that have not yet experienced improvements in commercial maize production. These are rain-fed, marginal areas that are particularly vulnerable to climate change. The strategy is designed to develop and distribute non-transgenic variety and hybrid seeds to small farmers at a low cost, and provides an illustrative example of how to simultaneously strengthen public sector research capacity and private-sector dissemination capacity in ways that get needed materials into the field [62]. The STRASA project, which is co-ordinated by IRRI, involves NAROs, NGOs, farmer organizations and private seed companies from a number of countries. The foci of this project are on (1) the identification and characterization of promising and adapted local varieties; and (2) the improvement of seed dissemination systems based on adapted local varieties [63]. The Latin American and Caribbean Consortium to Support Research and Development of Cassava (CLAYUCA) and the Latin-American Fund for Irrigated Rice (FLAR) were created with the support of the CIAT to foster the development and use of cassava and irrigated rice-related technologies, respectively. Established in the 1990s as a response to shortages of public support for research, CLAYUCA and FLAR comprise alliances of cassava and rice producer countries that aim to improve the co-ordination and collaboration between public and private institutions [64,65]). The Pan African Bean Research Alliance (PABRA) has evolved from a CIAT project to an African partnership program. It facilitates collaborative research within and among networks by providing a forum for building and strengthening linkages among multiple partners such as researchers, NGOs (including the private sector), community-based organizations and farmers [66,67]. 
The adoption of a much more active role at the dissemination stage has raised a number of questions and taken many CGIAR breeders out their traditional comfort zone. How much should the CGIAR centers become involved in promoting and supporting the adoption of improved varieties? Does this role fall on the centers as much as on the national partners? Many breeders are not completely comfortable with the CGIAR's increased engagement in development activities, not only because these efforts limit their time for pure research activities (particularly in those centers where financial resources are insufficient to increase staff), but also because release and dissemination have traditionally been considered the responsibilities of NAROs. Thus, some interviewees were concerned that the legitimacy of the CGIAR centers to intervene in this area could be questioned. In some cases where the centers have become very much involved in these tasks, they have found themselves in competition (or perceived competition) with national institutions, and, in general, it is not clear if this is the most efficient way of distributing responsibilities between international and national actors. Many breeders stress the need for the CGIAR to maintain a low profile and adopt a facilitating role in development instead of an executing one.

An important issue that underlies the uncertain role of the CGIAR centers' breeders in this regard, concerns the changes that are occurring in national agricultural research systems and related national agricultural development and research policies. In some countries, the public sector has further reduced its already weak presence in downstream activities. Reasons for such weakness include a lack of human and financial resources, low policy priority and poor infrastructure. In other countries, the public sector has concentrated its efforts on fewer crops, has shifted its priorities and resources to other activities (for example, biotechnology) or has begun to privatize certain services, for instance, seed production and marketing and agricultural extension.

In some other countries, however, there has been an increase in the public sector's interest and efforts in relation, for example, to the dissemination of improved varieties and seed production. As some of the interviewees mentioned, this increased interest has sometimes included requests and resources made available to the CGIAR centers - for instance, ICRISAT and IRRI - to cooperate with NAROs on these efforts. In certain countries where there is an increase in public agricultural investment, some of that investment is to support the centers' direct, downstream participation in the seed system.

\subsubsection{Increased Collaboration with the Private Sector}

According to a study conducted by the CGIAR's Science Council Secretariat [68], the private sector represented only $6 \%$ of the 3395 organizations working in collaboration with the CGIAR centers in 2006. Therefore, the private sector's role in the CGIAR was relatively minor compared to the role of its traditional partners in the public sector, but it has increased considerably in the last decade through new cooperative links, including those with manufacturers and processors [69].

The role of the private sector has become particularly prominent in the stage of technology and germplasm dissemination [70]. In many developing countries, the public sector has been inefficient in terms of seed production and marketing, particularly when addressing the needs of the small and most vulnerable farmers. Combined with the growth of private seed enterprises in a number of countries 
(mainly in Asia and Latin America), these factors have led to strengthened collaboration between the CGIAR centers and private seed actors.

The experiences of CIAT's CLAYUCA and of ICRISAT's Hybrid Parents Research Consortia have been documented as successful partnerships in this regard [64,71]. Enhanced capacities to test materials in diverse environments, guaranteed seed quality control and agile seed-multiplication skills have put private companies in a better position to make improved varieties available to farmers in certain countries and contexts.

Nevertheless, there is no clearly elaborated CGIAR system-wide vision and strategy on public-private partnerships, although the need for new partnerships of all kinds has been stated in the 2011 strategy and results framework [56]. Existing public-private partnerships have not been thoroughly evaluated, for example, in terms of their contribution to poverty reduction [72]. With respect to partnerships for biotechnology generation and dissemination, Ayele et al. [73] criticize many of the partnerships in Africa that involve the CGIAR centers. They argue that these collaborative efforts tend to be supply driven and not always linked to user demand and assert that such partnerships have often sprung from given "solutions" that have not been clearly linked to national development goals.

Incentives for private sector involvement are limited in those regions that are most vulnerable to climate vagaries (marginal, rain-fed lands, with mostly subsistence farmers) or for crops with greater potential under stressful environmental conditions (legumes and dryland crops). The focus of private industry in these regions is on a different range crops and agricultural production systems (irrigated crops), which may leave the CGIAR centers no option other than to partner with public actors. ICARDA's work in the Middle East and North Africa is an example. Some interviewees explained that the continued role of public investment and international-national public sector collaboration, particularly for marginal areas and "minor" crops, remains important.

\section{Policy Issues Related to the CGIAR Centers' Access to Germplasm for Conservation and Breeding Purposes}

\subsection{The Impact of International and National Laws on Access and Benefit Sharing}

The rules governing the access to, and use of, genetic resources have changed dramatically, as demonstrated by the Agreement on Trade-Related Aspects of Intellectual Property rights (TRIPS Agreement) in 1992, the Convention on Biological Diversity (CBD) in 1993 and the ITPGRFA with its multilateral system of access and benefit sharing in 2004 [74]. While twenty years ago germplasm was collected, conserved and exchanged in a relatively open system of flows among different users of plant genetic resources, these activities are now much more subject to international and national regulations. The development of these regulations occurred when the internationalization of ex situ conservation and crop breeding and the expansion of intellectual property rights raised tensions among nations about who would bear the cost of conservation and who would benefit most (commercially) from its use.

The transformation of international agreements that affect germplasm exchange and use into national level measures has proven challenging [75] particularly with regard to access and benefit-sharing questions [76,77]. This situation has obviously affected the operations of the CGIAR centers with 
respect to activities that lie at the core of their mandates, such as collecting germplasm for conservation and research purposes and transferring gene bank and breeding material to other users. This difficult transformation can hamper the easy access of germplasm for research and development of new plant varieties in response to climate change.

Our interviews with scientists confirmed that it is becoming increasingly difficult for the CGIAR centers to obtain access to germplasm for inclusion in their gene banks or breeding programs. In general, respondents noted that it is particularly difficult to obtain germplasm from developing countries, although one developed country was also mentioned in a number of interviews. Gene bank managers and breeders most often mentioned the largest developing countries in this regard, ones which have (1) a large diversity of the CGIAR center's mandate crops; (2) strong agricultural research programs; and (3) long histories of accessing and using different kinds of materials from the centers' gene banks and breeding programs. In this context, it is important also to recall that these countries are also among the largest providers of materials in the CGIAR center-hosted collections. However, most of these materials were collected and transferred to the centers in the 1970s and 1980s. Overall, the interviewees highlighted a shift away from willingness to make germplasm available over the last 10 to 15 years, and all of them expressed strong concern about this trend.

Most gene bank managers and breeders interviewed attributed their difficulties obtaining access to new genetic diversity to three factors: (1) a combination of high levels of politicization of genetic resource issues and "inappropriate" policy initiatives, including what they called "strong" (restrictive) access and benefit-sharing regulations (as a result of the CBD); (2) pressures to globalize intellectual property rights through international trade agreements and (3) insecurity on the part of officials about actually agreeing to provide materials to the CGIAR centers. Similar findings were documented based on interviews with CGIAR gene bank managers in 2005 and 2006 [6]. Although a restrictive approach has become common, it is important to point out that the interviewees noted considerable differences among countries. For example, scientists from a few centers indicated that germplasm access from a number of African countries is not particularly difficult but is limited by a lack of funds and human resources needed to set up strong collaborative research initiatives and the formal and informal networks under which germplasm can be exchanged.

Most respondents observed that the ITPGRFA and its multilateral system of access and benefit sharing are not having a significant positive impact on the willingness of previously reluctant providers to make germplasm available. Some respondents thought that the treaty might have made things worse. Among the factors they cited in this regard were: the perceived complexity of putting mechanisms in place at the national level to implement the multilateral system; the fact that germplasm providers have not (or not yet) actually received any benefits through the treaty's benefit-sharing mechanism, and the fact that some crops were not included in the list of crops covered by the ITPGRFA's multilateral system (commonly referred to as Annex 1 crops, since the list can be found in such annex of the treaty), has encouraged countries to take a restrictive approach to access. Others opined that while acceptance of the SMTA and the treaty's multilateral system of access and benefit sharing has been slow initially, providers will eventually be more willing to make materials available through that system. It was acknowledged that increased willingness would not happen automatically but would require new action by provider countries and the respective authorities in charge of implementing the treaty. 
Interviewees mentioned that strength and longevity of relationships among individual CGIAR centers and countries were factors that helped to overcome some of these challenges. They also said that larger research projects, in which transfers of genetic materials are supportive of broader research objectives, can be instrumental. Scientists involved in international germplasm improvement networks noted that long-term co-operative links (for example, through the INGER network led by IRRI [78]) are less affected by the reduced willingness of countries to share germplasm. As explained in a previous section, the primary goal of these cooperative networks is to sustain scientific and technical work, but they also may have a positive effect at the national policy level by assuaging national concerns around the sharing of national germplasm and demonstrating the positive effects associated with valuable outcomes to research. However, the existence of long-term relationships and networks does not automatically imply the smooth exchange of germplasm. A few scientists pointed out that national policies and regulations, particularly those related to access and benefit sharing and intellectual property rights, have begun disrupting even those networks that used to be very functional. They observed that restrictive behavior by some countries is affecting the overall effectiveness of these international networks.

For some crops, the relative importance of the lack of access to germplasm may be tempered by two factors: (1) there is considerable unexplored germplasm in the CGIAR gene banks; and (2) breeders have a fair amount of improved materials at their disposal. On the other hand, in all cases, gene bank managers and breeders confirm that there is germplasm in other countries that they would like to obtain access to, particularly of wild crop relatives. All of the interviewees stated that while the ongoing drop in germplasm flows may be acceptable for some crops in the shorter term, in the longer term, particularly as a result of climate changes, access to plant genetic diversity from beyond the international collections and extant breeding lines will become increasingly important. Shifts in pest and disease patterns, which are among the most significant effects of environmental changes, would necessitate exploration and transfer of traits that may not now be represented in the CGIAR collections. Prior work has shown that lack of access to new germplasm, for crops such as soybeans, yams, banana, groundnuts and forages, is already limiting breeding possibilities, because neither international gene banks nor open national collections such as the one held by the United States Department of Agriculture (USDA) maintain a sufficiently diverse collection of germplasm, particularly in terms of wild relatives [79]. While some countries have been collecting significant amounts of new germplasm, including wild relatives [80], only some of them report significant rates of providing germplasm beyond their own borders, including to the CGIAR centers.

A number of the centers reported receiving increasing amounts of material under restrictive material transfer agreements and having to reject germplasm whose use is subject to too many limitations. They have had to refuse germplasm because they were not allowed to pass it on to other users. Examples mentioned by interviewees include parental lines of legumes and wild species of Zea. Problems derived from the inability to transfer accessions received from national partners have also arisen when assembling reference sets from gene bank core collections for gene discovery under the Generation Challenge Programme (GCP) [81]. As one of the scientists involved in the GCP explained, reference sets provide a representative sample of crop diversity to help coordinate upstream research by organizations all around the world. The omission of diversity from any collections in the development of these sets potentially compromises their completeness and, thus, their utility. Some breeders 
reported other restrictive conditions concerning some materials - for example, the requirement to grant first access to research results to the germplasm or technology provider.

\subsection{Increasing Intellectual Property Protection and Its Effect on the CGIAR Centers'Ability to Use} Germplasm and Associated Technology

Debates concerning access to plant germplasm and technologies subject to intellectual property rights have been chronicled extensively in the literature since the late 1970s [82-86]. They became particularly inflamed following the 1994 adoption of the TRIPS Agreement, which requires all member countries of the World Trade Organization to adopt minimum standards of intellectual property protection. More recently, growing attention has been paid to understanding the implications of using intellectual property rights to protect technologies (including plant germplasm) that hold promise for mitigating and/or adapting to climate change.

Prior work has shown the simultaneous growth of applications for patents and plant breeders' rights seeking control of the exploitation of plants, plant varieties and their seeds. This has been particularly evident in both developed countries and emerging economies [87,88]. Applications by public research agencies account for a considerable degree of this increase, which is in some cases enabled by public policy modeled on, or similar to, the U.S. Bayh-Dole Act (1980) [89], which amended the patent and trademark law to allow universities, small businesses and non-profit institutions to pursue ownership of inventions developed with federal funding. Empirical evidence of the precise impact of intellectual property protection on crop-improvement efforts in developing countries is scarce, however. Focusing on the research and commercialization of protected plant germplasm of staple crops in developing countries, Koo et al. [87] emphasized that concerns around intellectual property rights are overstated. Although both the scope and the geographic extension of protection are expanding, the preponderance of protection pertains to high and medium-high income countries, leaving poor countries free to tap these technologies. Moreover, based on the number of applications for plant patents and plant breeder's rights in different jurisdictions, these authors indicate that many of the protected varieties are ornamentals, not food crops. In addition, most plant varieties are afforded protection that enables rights holders to limit or exclude others from marketing, but not breeding, the protected material. This degree of protection offers researchers in both developed and developing countries the freedom to use such varieties in their breeding activities.

The CGIAR scientists and intellectual property specialists who were interviewed generally confirm that intellectual property rights are not posing a significant hurdle for the CGIAR centers to obtain access to technologies they need as inputs for their crop-improvement efforts. Several factors may account for this silence. Most of the centers did not report needing to obtain, or trying to obtain, access to proprietary technologies for their crop-improvement work. For some of the centers' mandate crops, the private sector's investments in crop improvement is relatively low, with the result that companies are not generating the elite germplasm that might be protected. Indeed, it seemed that the opposite situation is often the case; it is the centers that are producing the improved germplasm that the private sector wants to access, such as parental lines for commercial hybrids.

Another reason that was given is that there are no relevant intellectual property laws in many of the countries where the CGIAR deploys its technologies. An example cited in the literature illustrates this 
particular scenario. Many thought that the main obstacle for making the vitamin A-fortified cultivar "Golden Rice" available would be the large number of patents involved in the development of the product -70 patents belonging to 32 different patent holders around the world with Syngenta being the most prominent [90]. The negotiation process of the licensing agreements between the fortified rice producers and the patent holders lasted less than six months, allowing Golden Rice to be exploited for the public good (with certain limitations). The unexpected low transaction costs and the successful partnership between public and private actors were not the only interesting aspects of the case. Most of the patents identified are not applicable in the top 10 rice-producing countries [90] nor in many of the countries that suffer the most serious levels of vitamin A deficiency and are also major consumers of rice [91].

The interviewees also explained that when the CGIAR centers consider using advanced germplasm and technologies from public and private entities in developed countries (for example, molecular markers and other pre-breeding tools or transgenes), the technology is often outdated and the patent has expired or is not subject to intellectual property protection in the countries where the CGIAR wants to deploy them. Some breeders made reference to some cases in which the centers gained access to technologies subject to intellectual property protection under affordable conditions. For example, as part of the Generation Challenge Programme, centers and national partners sought access to pre-breeding advance technology owned by research institutes and private firms in the developed world. National and international public organizations joined efforts to get access to such technologies under affordable conditions. Having said all this, some of the scientists and intellectual property specialists who were interviewed concurred that the existence of patents or intellectual property rights over a needed technology increases transaction costs. They pointed out that these costs could delay access to, and use of, such technology in comparison to those technologies that are not subject to intellectual property protection.

Breeders and intellectual property managers shared their concerns about a number of cases in which national institutions have protected certain varieties that had resulted from germplasm improved by the CGIAR centers and exploited those varieties in a restrictive manner and/or without informing the centers. CGIAR scientists have attributed various motivations to the national scientists' desire to seek variety protection and have indicated that such actions were often backed up by national policies. They mentioned that there are incentives for national programs to inflate their own contributions and ignore those of the CGIAR centers. Government funding for national programs depends upon demonstrating contributions to the improvement of national production. Incentives to inflate national contributions seem to have increased in countries where variety registration laws and/or plant variety protection laws have recently been put in place or updated. As a result, breeders are being rewarded according to the number of varieties they register. It was also noted that, in one country, the recent adoption of a national policy similar to the Bayh-Dole Act [89] in the United States was creating an incentive for national agencies to be more aggressive about seeking intellectual property protection over new crop varieties. In order to deal with this situation, some of the CGIAR centers have adopted defensive strategies to protect their contributions. In 2005, ICRISAT signed a memorandum of agreement (MOA) with the European Patent Office (EPO) allowing ICRISAT to include its publications as part of the EPO's non-patent literature. Thanks to this agreement, information and knowledge generated by ICRISAT is being provided to European patent examiners for consultation in prior art searches. CIAT 
has intended to follow ICRISAT's example, but a parallel MOA has not been implemented. CIAT has not abandoned this approach, however, and is considering signing an agreement with the Colombian patent office. IRRI, in cooperation with Philippine authorities, is developing a public register of germplasm collected before the ITPGFRA's entry into force. The aim is to defeat spurious novelty claims in possible plant variety protection or patent applications over such germplasm in all other countries. Some centers are also considering proactively protecting some of the varieties that they have improved by claiming plant breeders' rights to limit germplasm users' ability to apply exclusive rights over the use of such varieties at a future point in time. Some cases of misuse of publicly-made available varieties have already occurred, such as a yellow bean of Mexican origin (which became known as the "Enola" bean, for which twenty years later that it was released in Mexico, a patent was claimed by a U.S. company (in 1999). The claim was successfully contested by CIAT, the FAO and the ETC group and overturned by the U.S. Patent and Trademark Office in 2008 [92].

\section{Policy Issues that Limit the Distribution of CGIAR Germplasm}

The CGIAR centers fulfill a very important role as drivers in the global movement of germplasm, both from their own crop-improvement programs, and from the international collections of germplasm that they conserve and curate. In light of continued, and in some cases increasing, restrictions on the access to and use of germplasm worldwide, the centers' role in this regard becomes more important (and anomalous) as time progresses. The collections hosted by the CGIAR centers' gene banks include germplasm originally collected from 195 countries. By physically pooling those resources, investing in their conservation and making them available, the centers allow countries to avoid the enormous (often prohibitive) transaction costs they would face if they had to independently search for and negotiate a supply of the same genetic resources from each supplier country. This is particularly important given that so many countries are currently opting not to share much or any PGRFA beyond their own borders. If those countries had not previously agreed to allow the centers to conserve and distribute those genetic resources, many of them would not be available now. These genetic resources are only currently available due to the less restrictive, historical approaches of source countries, and because the centers and a few countries continue to invest in their conservation and distribution.

In the following subsections, we analyze the extent to which policies - at organizational, national and international levels - are supporting or creating challenges for the centers' breeding programs and gene banks to continue to act as international drivers for center-improved germplasm and germplasm conserved in the gene banks. We will also examine how policies affect the subsequent diffusion and uptake of germplasm distributed by the centers.

\subsection{Challenges Related to the Distribution of Germplasm under the Multilateral System of the ITPGRFA}

As stated above, the legal status of the ex situ collections hosted by the CGIAR gene banks was confirmed by the 1994 FAO-CGIAR in-trust agreements and, more recently, in 2006, through agreements between the CGIAR centers hosting collections and the governing body of the ITPGRFA. Those agreements confirm, for the first time, within the context of an international legally binding treaty, the centers' ability to continue their role in facilitating international access to the "in trust" materials held in the gene banks (of both Annex 1 and non-Annex 1 crops) for the purposes of 
research, breeding and training for food and agriculture. Pursuant to those agreements, the centers also agreed to use the SMTA when distributing germplasm that they have improved when it incorporates "in trust" germplasm, or any other materials in the multilateral system of access and benefit sharing. In such cases, if the materials are still under development, while the CGIAR centers are obliged to use the SMTA, they may add terms and conditions that can apply until the development process is finished and the final product commercialized on the open market [93]. As such, the treaty, combined with the centers' agreements with the governing body, provides a solid legal basis for most of the distributions of genetic resources from the CGIAR gene banks and breeding programs.

As reported in the fourth session of the governing body in 2011, during the first three years of operating under the treaty's framework, from January 2007 to December 2009, inclusively, the centers' gene banks and breeding programs together distributed 1.15 million samples of PGRFA. "Approximately $84 \%$ of the samples were sent to developing countries or countries with economies in transition, $9.5 \%$ to developed countries and $6.5 \%$ to CGIAR centers. $18 \%$ were sent by the centers' gene banks, and $82 \%$ from the breeding programmes" [94].

In general, CGIAR scientists seem to have a good understanding of the SMTA and feel comfortable using it. Respondents in one center thought that familiarity with the SMTA and its use was considerable at the headquarters but was lower in regional and country offices. According to the experience of gene bank managers and breeders in most of the centers, the use of the SMTA for the transfer of material is not causing major difficulties with traditional public recipients, although there have been complaints about the length of the review and signature process. The CGIAR centers have made considerable effort to help recipients become familiar with the ITPGRFA's multilateral system and the SMTA. Explanations about the multilateral system can be found on the websites of some centers. CIMMYT and IRRI have posted frequently asked questions related to the multilateral system and the SMTA, and IRRI has developed tutorials. In addition to frequently asked questions, the SGRP has developed a guide for the CGIAR centers to use in relation to the SMTA, which provides guidance on how to deal with different issues related to the transfer of CGIAR germplasm [95]. In the context of expanding public-private partnerships and their relevance for climate-change research and development, CGIAR scientists have provided formal and informal guidance on the SMTA to private companies involved in ICRISAT and IRRI hybrid consortia. CIMMYT staff has made similar efforts for public and private members of large projects such as CIMMYT's MasAgro with the aim of reassuring them that the SMTA is acceptable.

However, there are still a number of distribution-related uncertainties and challenges associated with the Treaty's multilateral system and the centers' agreements with the governing body. These issues can be divided into two groups: issues related to how the centers operate within the scope of their agreements with the governing body, and issues related to how they operate beyond the scope of those agreements.

Perhaps the most pressing question within the scope of the agreements concerns "what additional terms and conditions can a center add when it is distributing 'PGRFA under development"'? Can they restrict access to materials or seek intellectual property rights over them, or allow other to seek IPRs over the germplasm they have improved? Strictly legally speaking, the centers' discretion with respect to the first question is fairly broad. However, for years, there have been questions raised by center scientists, donors, and other about the conditions under which the centers should enter into agreements 
whereby they limit access to their research products. The recently adopted CGIAR Principles on the Management of Intellectual Assets [96] have the practical effect, as a matter of CGIAR system-wide policy, of narrowing the centers' discretion under the treaty, by establishing minimum threshold justifications for centers entering into exclusive arrangements, and obliging them to various forms of disclosure. The Intellectual Assets Principles are new, with the centers operating under them only since March 2013. It will take some time before their relevance to centers distributing PGRFA under development are fully understood and lessons can be learned and synthesized. They will be subject to review within two years.

Another frequently raised question concerns "how much money can a centre request when supplying PGRFA from its gene bank?" The SMTA says "when a fee is charged, it shall not exceed the minimal cost involved." As the centers move into full cost recovery, it becomes very important to ascertain how much of the cost of conservation can be considered "minimal" under the treaty?

A third issue has to do with the impracticality of using the SMTA when the centers distribute materials to farmers on farmer field days, or in the context of projects that involve participatory variety selection and participatory plant breeding. Often the farmers are illiterate and likely to be disconcerted when presented with the 12-page SMTA to approve. So far, the best that can be suggested is that the centers follow processes that are commonly accepted in the countries concerned for explaining contracts to illiterate farmers as a precursor to their being able to express consent. Even more impractical is the expectation that farmers will pass on seeds, through their informal contacts with other farmers, by using the SMTA and documenting consent.

Two closely related outstanding issues that arise at the fringes of, or beyond, the centers' agreements with the governing body, are:

- Does a CGIAR center gene bank have the right to distribute materials for non-food/non-feed purposes (purposes other than those listed in the Treaty), for example, for biofuels-related research? If so, under what access and benefit-sharing conditions can these materials be distributed?

- Can a center gene bank distribute materials to farmers for direct use? (Direct use in cultivation is also not included in the purposes for which materials are made available under the Treaty or the SMTA.) If so, under what terms and conditions?

These are issues that have been raised repeatedly by CGIAR scientists since signing agreements with the governing body [97]. Two years ago, the centers also submitted a request for feedback on these issues to the Ad Hoc Technical Advisory Committee on the SMTA and MLS (TAC-SMTA) which was created by the Governing Body of the Treaty. At its third meeting, in July 2012, the TAC-SMTA confirmed its opinion that the centers can distribute materials they developed, and materials they held in trust under the 1994 in-trust agreements, for non-food/non-feed purposes and for direct use to farmers, and that the centers should not use the SMTA for these purposes [98]. While the opinions of the TAC-SMTA are not legally binding, they nonetheless provide some "cover" for the centers and their practices, in as much as the centers can argue that they exercised due diligence by obtaining an opinion from the TAC-SMTA. It is also a good practice for the centers, as a means of demonstrating their commitment to transparency, to refer such issues to the attention of the TAC-SMTA. 
Finally, it is important to note that some private companies and universities that work closely with companies have expressed reservations about receiving materials under the SMTA, and some have adopted policies to avoid accepting such materials if possible. In general, companies and universities that anticipate patenting PGRFA products are most vocal in this regard, though the International Seed Federation published a critique of the SMTA (presumably on behalf of all its members) as early as 2007 [99]. However, respondents from various centers also reported that some U.S. universities do not accept the SMTA because the arbitration clause conflicts with federal laws to which the U.S. universities adhere. The most frequent complaints from private-sector partners with respect to the SMTA concern a number of points summarized in the following list.

- The SMTA imposes an obligation to pay back to a "benefit-sharing fund" in the case that a product derived from the use of the received germplasm is subject to protection and already commercialized. Companies have often not heard of such an obligation, and it is uncommon, legally speaking.

- The SMTA does not specify a time limit, which, in terms of duration, makes this obligation more restrictive than a patent. Companies are not clear whether and when the obligation expires. Is it in perpetuity?

- Usually, breeders calculate royalties to be paid according to how much of the original material is incorporated in the final product. It is understood though that, if the final product incorporates less than $12.5 \%$ of the original germplasm, there are no royalties to be paid. Breeders are not comfortable with other "rules".

\subsection{Intellectual Property Right-Related Challenges}

Earlier sections of this paper looked at the increased involvement of the private sector in the dissemination of new CGIAR germplasm, which is clearly a trend that emerges from this study. The involvement of private firms in the CGIAR work has raised issues related to intellectual property rights over what were traditionally considered global public goods. Some of the recent agreements with private firms have a clear commercial nature. The establishment of hybrid consortia, which were explained above, includes payments to the CGIAR centers (in the form of fees) in exchange for access to improved materials. Some of the centers have received royalties from industry's use of advanced germplasm. IRRI is currently developing a center-wide policy that includes the payment of royalties when IRRI-improved material is used for commercial purposes.

Approaches to partnerships, particularly regarding issues related to intellectual property rights, have tended not to be consistent across the CGIAR [100]. Some of the CGIAR centers address contractual obligations, and particularly intellectual property rights, in a formalized, systematic manner. Others have not had a specific procedure or policy but have tended to act on a case-by-case basis. All of the interviewees stressed that ensuring the wide dissemination of technologies is the inspiring principle behind all dissemination strategies. However, they pointed out that in order to ensure such a goal and to keep it at an affordable price, the centers sometimes need to accept restrictions on their ability to distribute materials they have developed, to create incentives for companies to invest in further improving or distributing the material in question. Again, the recently approved CGIAR Principles on Intellectual Assets set the rules for all centers concerning the conditions under which they may restrict 
the availability of their assets (including germplasm), the kinds of restrictions they may use and how much information about such arrangements they must disclose, and to whom. The principles are expected to bring order to the range of center practices.

\subsection{Phytosanitary Requirements}

Phytosanitary requirements are central to proper germplasm acquisition and distribution. All germplasm samples for both import and export pass through the germplasm health units of the CGIAR centers to ensure that the germplasm meets the host-country import and export requirements. Cleaning and inspection processes become more time and resource consuming, as national regulations become stricter and better enforced, and as plant-safety standards increase thanks to the improvement of technologies used to detect pests and diseases in plant samples. Some gene bank managers and breeders noted that certain countries have adopted phytosanitary policies that have led to lower acceptance rates of genetic materials. Phytosanitary experts in some of the centers indicated that there are also countries that do not have the capacity to carry out all the analyses that their phytosanitary policies require. The result is that the countries concerned cannot accept particular germplam or they must request assistance from specialized agencies in other countries. This requirement, in turn, leads national scientists to stop making requests because they know the germplasm will not reach them in a timely manner or at all.

\subsection{Variety Release Procedures}

Many developing countries have established variety registration and release systems inspired by seed laws in European countries [101]. The adoption of the "European model", however, has not always responded to local conditions. Formal release systems suit only a very small portion of the seed market in many developing countries. The formal sector provides less than $5 \%$ of the seed used to produce the traditional staple crops (sorghum, millet, cowpea) in West Africa; less than 10\% for rice, wheat and maize production in Nepal, and from $1 \%$ to $13 \%$ for wheat, barley and legume production in Morocco. Around $75 \%$ of the major fruit tree resources that are crucial to the economy of Central Asia come from informal and local sources [102]. Limited capacities and resources of both breeders and national agencies in charge of variety release have resulted in lengthy (and sometimes uncertain) procedures to test candidate varieties.

As the dissemination of improved germplasm gains a prominent place in the CGIAR centers' core activities, national laws regulating plant variety registration and seed commercialization become more and more influential in the success of the centers' breeding activities. The breeders that were interviewed stated that variety testing and some kind of formal release are necessary steps for guaranteeing the identity and quality of new varieties and for making them available for public and private agencies to multiply and distribute. The same breeders, however, complained about the length of time the current procedures take in many countries. In some cases, it can take more than five and up to ten years. They observed that the testing procedures at the national level often repeat what the CGIAR centers have already accomplished.

Another bottleneck identified by interviewees is the rigidity of the varietal registration criteria (which require plant varieties to be highly uniform and stable) and the costs involved in variety 
registration and seed certification. These two factors can put traditional cultivars and new varieties developed by the centers through PPB in a disadvantageous position. PPB varieties, including those specifically developed to be able to adapt to climate change, typically remain outside the formal mechanisms of seed production and dissemination as well as those for benefit sharing [103,104]. Seed from such varieties does circulate among farmers through informal means, but the fact that they have not gone through the formal registration and quality control procedures puts them in a disadvantageous market situation. Such seed is neglected when the use of certified seed of registered varieties is recommended by extension services, linked to credit facilities and subsidies, or is required by processors [105-107].

The existence of a single, officially recognized seed-supply system that includes only formal approaches to variety recognition discourages the development of alternative mechanisms for seed supply for many of these varieties [108]. The end result is that the seeds preferred by farmers (and local consumers) may not be available in sufficient quantities [109-111]. The potential benefit of decentralized, participatory approaches for germplasm evaluation, selection and dissemination in communities and areas most exposed to climate vagaries can be significant. Any obstacle in the subsequent diffusion and upscaling of these efforts, starting with the complex procedures for seed certification, could reduce the advantages of community-based efforts. Some of the social scientists who were interviewed from IRRI, for example, mentioned that they have been facing this obstacle in some of their work [112].

As noted earlier, some projects are currently underway that will put into place variety and seed-quality control mechanisms that also serve germplasm users in the informal sector of seed multiplication and dissemination. Different models have been proposed and tested to incorporate differing methods of seed production and supply. While keeping the formal system's original objectives of providing transparency and ensuring seed quality, these models are trying to address information gaps commonly found in informal seed systems, by regulating the commercialization of traditional and modern varieties in a way that better adapts to the needs of small farmers. The Quality Declared Seed System (QDSS) proposed by the FAO [113] has been widely used in areas where seed markets are not fully functional and governmental resources too limited to effectively manage comprehensive certification systems. Under QDSS, seed producers are responsible for quality control, while government agents test only a very limited portion of seed lots and seed multiplication fields. The system has been recently revised with the aims of recognizing the role of national policies and providing clearer explanations of how quality-declared seeds can accommodate local varieties [114].

The CGIAR centers have been actively involved in policy processes aimed at adapting seed laws to national circumstances and experimenting and promoting alternative schemes of seed production, variety registration and seed certification. CIAT initiated such efforts in the second half of the 1990s in eastern Africa [115-117] and, more recently, in Ethiopia [118]. CIMMYT has made efforts in developing community-based seed production strategies in eastern and southern Africa [119]. At the regional level, the CGIAR centers located in Africa have played a facilitating and advisory role in the negotiations leading to seed law harmonization. The diffusion of varieties across regions may be limited by the country-specific seed certification rules. Efforts for regional harmonization are underway in several parts of the world. Through a participatory process involving the key stakeholders in various countries, a legal framework for the harmonization of seed legislation is being developed 
and subsequently adopted by the regional bodies. Once implemented at the country level, such regional agreements can ensure that an improved variety registered in one country is automatically considered to be registered in other countries within the same region. Thus, seed can be multiplied and sold in these other countries, potentially contributing to the more rapid dissemination of 'climate smart' material and practices across regions [120].

\subsection{Subsidies and Their Effects on Germplasm Availability}

Subsidies are a commonly used instrument to promote the adoption and diffusion of new agricultural technologies by lowering the initial risks and the cost of learning to use a new technology [121]. By overcoming temporary market failures, which offset the fixed costs of infrastructure and reduce risk, subsidies can enhance the use of inputs (seeds of improved varieties, fertilizer, pesticides and credits) for increased agricultural production, which, according to some studies, may eventually contribute to poverty reduction [122]. There are a number of examples of how subsidies and other public support mechanisms have contributed to the spread of particular crops and crop varieties. Without public support in the form of incentives, information and infrastructure, the Green Revolution in Asia would not have been successful. The diffusion of high-yielding varieties of wheat and rice, particularly in India and China, was made possible through strong policy support and investment in agricultural research and development [123,124]. Similarly, economic incentives, including subsidized seed and maize-based food prices, have been key in the adoption and dissemination of improved maize varieties in Africa [125].

Some breeders that were interviewed had positive impressions about the use of subsidies to support agricultural development. They mentioned, for example, a project initially launched by ICRISAT on the use of a technology package (machinery for drainage, seed and fertilizer) for the production of cereals in the Ethiopian Vertisols. This project reached its objectives only when the Ethiopian government started to subsidize the adoption of this package by farmers. However, subsidies can have perverse effects as well. Several studies in Africa have shown that the subsidized distribution of seed of major crops, such as maize, discourages seed-enterprise development in the long term [126,127].

Subsidies are also increasingly recognized to potentially hinder the demand for, and the use of, crop diversity in agricultural production. Such efforts could hamper adaptation to local climate change. Subsidies are generally provided for improved varieties of major cereals (rice, wheat and maize) through public distribution systems. This action often results in disincentives for farmers to cultivate other crops including those that their livelihoods depend on, such as small grains, legumes and tubers $[128,129]$. Subsidies can also have a negative impact on the use of traditional varieties of such crops or of varieties developed through alternative breeding approaches. Some studies show how, in the Philippines, widespread government subsidies for hybrid rice have distorted the ability of farmers to make informed choices between growing hybrid and inbred rice varieties. The result has been the limited adoption of hybrid varieties, contrary to the original objective. The program has not only been ineffective but also costly in terms of wasting scarce budgetary resources. It has also compromised the government's regulatory functions and promoted corruption [130,131].

Interviewees confirmed that, in several Asian and Latin American countries, seed delivery and adoption patterns have been affected by complex public subsidy schemes, which are not exclusively 
aimed at the development of agriculture. For example, in Mexico, the poverty-reduction program "Opportunities" has influenced the way in which small farmers adopt and use both hybrid and traditional maize varieties in a variety of ways [132]. In India, traditional crops, such as millet, sorghum and pulses, which are important for food security of small farmers in marginal areas, are not covered by subsidized public distribution systems, while other crops are, such as rice, wheat and maize. If seed of a variety developed or promoted by a CGIAR center and/or its partners is not picked up and disseminated through the state seed corporations in India, its higher, full-market cost will act as a significant disincentive to would-be consumers. Subsidies are also available for fertilizers, machinery, irrigation and other agricultural inputs [133]. The national Indian program of subsidized food systems for the poor promotes the consumption of foods based on wheat, rice, maize and sugar [134]. According to the interviewees, it is having an indirect, negative impact on the demand for food based on improved varieties of pearl millet, sorghum, pigeon peas and other minor crops. In this case, ICRISAT (and other CGIAR centers) have joined in a national campaign to have foods from a wider range of regionally appropriate crops included in the nationally subsidized food program.

\section{Synthesis of Findings}

The findings presented in the previous section confirm that certain policies affect the conservation and use of PGRFA by the CGIAR centers and the dissemination of CGIAR-improved germplasm first to partners in agricultural research organizations and then to final users of new plant varieties developed through research partnerships.

It appears that, broadly considered, access and benefit-sharing policies are perceived to have a significant negative effect on the centers' conservation and breeding activities. However, degrees of concern expressed about this effect vary considerably within the centers, within the breeding programs of individual centers and across the centers themselves. The only strong and common voice of concern expressed referred to certain developing countries with a long history of collaboration with the CGIAR and whose conservation and research capacities have increased considerably in the last decade.

Until recently, most NAROs - particularly in developing countries - did not have the capacity to conserve, make available and use germplasm for breeding purposes. As a result, the understanding was that CGIAR gene banks needed, on their own, to collect and conserve the diversity of their mandate crops, and that CGIAR breeding programs were the main source of improved germplasm for the developing world. The scenario has changed substantially. In recent years, many of the partners of the CGIAR centers have strengthened their capacities to collect, characterize, evaluate and conserve germplasm. Some countries have initiated the building of new gene banks; for example, India, Nepal, Mexico, Turkey, and others have substantially increased the size of their collections or made significant improvements to facilities. Similarly, some large countries with rapidly growing economies, including Brazil, China and India, have made impressive investments in their public research programs on agriculture [135].

In this new scenario, an increasing number of national gene banks could have taken over part of the role traditionally played by the CGIAR centers in conserving and responding to requests for germplasm from all over the world, and national breeding programs with newly established capacities could have made their improved technologies more readily available to other countries, at least to 
developing countries in new south-south technology transfer initiatives. Indeed, the ITPGRFA's multilateral system of access and benefit sharing provides a legal and administrative basis for countries to become much more active as international germplasm providers of the 64 crops and forages included in its Annex 1. However, while the scene has been set to engage in an unprecedented level of global cooperation for the conservation and sustainable use of PGRFA, in practice, the recent situation has largely been static with many actors unwilling to assume more proactive roles in making germplasm available to the global community. The gradual politicization of issues around the use of genetic resources can explain this situation to a large extent. Developed nations' pressures to internationalize intellectual property protection over biological resources, developing countries tendency to exert their sovereign rights over such resources in a very protective way, and uncertainty and dissatisfaction with the way both providers and users of genetic resources meet (or avoid to meet) their obligations under the CBD have resulted in a situation in which national genebanks and breeding programs of a number of countries do not feel entirely comfortable sharing their germplasm.

Intellectual property rights do not seem to be posing major difficulties for the centers' use of germplasm and breeding technologies, a finding which is inconsistent with much of the literature which warns about the negative effects of the proliferation of intellectual property protection on agricultural research, particularly with respect to bottlenecks created through restrictions on upstream technologies and processes. Our findings suggest that as far as the CGIAR centers are concerned, intellectual property rights questions arise more in the context of centers' own strategies to promote dissemination of technologies developed by them, particularly when private partners are involved. The most important issue turns out not to be "will IPRs or other restrictions impact on the ability of centres to gain access to upstream technologies?" but instead "what IPRs and other restrictions will the centres exploit to advance the further development and diffusion of their own improved materials?"

According to the centers' experience in making improved germplasm available to farmers, a number of policies and legal frameworks may need to be revised in order to create a supportive environment for the development and effective dissemination of agricultural technologies. Among these, seed laws are probably the ones that deserve more urgent attention. While there is an increasing recognition of the role that informal systems of plant variety production, seed multiplication and dissemination and seed quality control play in making adapted germplasm available to farmers in developing countries, and while CGIAR centers and their international and national partners make an increased use of such informal mechanisms to enlarge the adoption and impact of improved germplasm, most laws in developing countries continue to acknowledge and support only formal crop improvement and seed commercialization methods. This perpetuates a system which may not respond to the dynamic needs of farmers and consumers in the developing world.

\section{Conclusions}

Our analysis highlights the ongoing importance of the role that the CGIAR centers have traditionally played as nodes for collecting and conserving germplasm for use by the international community and in developing and sharing improved germplasm. However, it also points to the fact that a wide range of PGRFAR users (from farmers to private companies) have a limited trust in internationally coordinated systems for conserving and sharing PGRFA. In the longer term, these 
circumstances will have a serious impact on the utilization of plant genetic diversity to cope with current and predicted challenges to agricultural production and, in particular, with climate change. A growing body of literature asserts that the successful adaptation of agricultural production systems to changes in climate will depend upon increased higher levels of access to, and use of, plant genetic diversity than is currently the case [136]. This assertion has been clearly recognized by the international community in the revised Global Plan of Action for the Conservation and Sustainable Use of Plant Genetic Resources for Food and Agriculture [137] and the Nagoya Protocol on Access and Benefit Sharing and the Fair and Equitable Sharing of Benefits Arising from their Utilization.

New partnerships established by centers, in particular with the private sector to achieve greater impact in terms of the adoption of research results and products (in particular for hybrids), while potentially extremely important, have given rise to new challenges in terms of the kinds of licensing arrangements the centers should enter into with the recipients of their improved germplasm. The development and recent adoption of the CGIAR Principles on the Management on Intellectual Assets respond to the need to harmonize practices across centers by imposing some minimum conditions to their capacities to grant exclusive rights to commercialize research products. To what extent the CGIAR new principles will be able to preserve the global and public nature of most of the CGIAR products will be seen once the centers, in collaboration with their partners, make the principles fully operational.

The reform of national laws regulating plant variety release and seed certification should be a priority for countries whose agricultural production needs to quickly adapt to changing climatic conditions. Participatory innovation schemes and lighter, more decentralized procedures for variety release and seed quality control may allow a more rapid dissemination of better adapted varieties. National subsidies related to seed pricing and availability need to mirror and support these decentralized approaches. As the CGIAR centers increase their own involvement in technology delivery processes, a critical analysis of their experiences with informal approaches to crop innovation and seed dissemination, including community seed enterprises, and participatory plant breeding, can help countries define practical measures to make seed regulations better adapted to their needs in relation to agricultural development, food security and climate change adaptation.

\section{Acknowledgments}

We would like to thank all CGIAR colleagues who facilitated our visits and interviews in the International Center for Tropical Agriculture, the International Centre for Maize and Wheat Improvement, the International Potato Center, the International Crop Research Institute for the Semi-Arid Tropics, the International Institute of Tropical Agriculture, the International Rice Research Institute and the International Centre for Agricultural Research in the Dry Areas, who took part in the survey and who showed us around the CGIAR gene banks, labs and fields. We thank Jennifer Guevara for her contribution during the initial stage of the study, Tom Hazekamp for his contribution to the analysis of germplasm transfers and Sebastian Pinzón for his help with Figure 1. We gratefully acknowledge the professional text editing by Stacy Belden. We also thank those who provided feedback to the CCAFS working paper No. 18, which showed initial results of this work. 


\section{Conflicts of Interest}

The authors declare no conflict of interest.

\section{References and Notes}

1. Pinstrup-Anderson, P.; Watson, D.D., II. Food Policy for Developing Countries: The Role of Government in Global, National and Local Food Systems; Cornell University Press: Ithaca, NY, USA, 2011.

2. Vernooy, R.; Song, Y. New approaches to supporting the agricultural biodiversity important for sustainable rural livelihoods. Int. J. Agric. Sustain. 2004, 2, 55-66.

3. Bioversity International, the International Center for Tropical Agriculture (CIAT), the International Potato Center (CIP), the International Center for Agricultural Research in the Dry Areas (ICARDA), the International Crops Research Institute for the Semi-Arid Tropics (ICRISAT), the International Institute for Tropical Agriculture (IITA) and the International Rice Research Institute (IRRI).

4. Data Base of the System-Wide Information Network for Genetic Resources (SINGER). Available online: http://www.singer.cgiar.org/ (accessed on 1 March 2012).

5. The legend classifies countries based on the number of samples sent to these countries from the CGIAR gene banks.

6. Halewood, M.; Sood, R.; Sackville Hamilton, R.; Amri, A.; van den Houwe, I.; Roux, N.; Dumet, D.; Hanson, J.; Upadhyaya, H.D.; Jorge, M.A.; et al. Changing Rates of Acquisition of Plant Genetic Resources by International Genebanks: Setting the Scene to Monitor an Impact of the International Treaty. In Plant Genetic Resources as a Global Commons: Challenges in International Law and Governance; Halewood, M., Lopez-Noriega, I., Louafi, S., Eds.; Earthscan: London, UK, 2013.

7. Food and Agriculture Organization of the United Nations (FAO). Report of the Commission on Genetic Resources for Food and Agriculture: Thirteenth Regular Session; FAO: Rome, Italy, 2011.

8. Developed countries include countries in transition.

9. Widrlechner, M.; Burke, L. Analysis of germplasm distribution patterns for collections held at the North Central Regional Plant Introduction Station, Ames, Iowa, USA. Genet. Resour. Crop Evol. 2003, 50, 329-337.

10. El Bouhssini, M.; Street, K.; Amri, A.; Mackay, M.; Ogbonnaya, F.C.; Omran, A.; Abdalla, O.; Baum, M.; Dabbous, A.; Rihawi, F. Sources of resistance in bread wheat to Russian wheat aphid (Diuraphis noxia) in Syria identified using the Focused Identification of Germplasm Strategy (FIGS). Plant Breed. 2011, 130, 96-97.

11. System-Wide Genetic Resource Programme of the CGIAR (SGRP). Booklet of CGIAR Centre Policy Instruments, Guidelines and Statements on Genetic Resources, Biotechnology and Intellectual Property Rights; SGRP: Rome, Italy, 2010.

12. Of the original 12 centres, the Centre for International Forestry Research did not sign the revised agreement. 
13. Standard Material Transfer Agreement; Adopted at the First Session of the Governing Body of the Treaty on Plant Genetic Resources for Food and Agriculture, Madrid, Spain, 12-16 June 2006. Available online: ftp://ftp.fao.org/ag/agp/planttreaty/agreements/smta/SMTAe.pdf (accessed on 8 August 2013).

14. Byerlee, D.; Dubin, H.J. Crop improvement in the CGIAR as a global success story of open access and international collaboration. Int. J. Commons 2009, 4, 452-480.

15. Evenson, R.E.; Gollin, D. Crop Variety Improvement and Its Effect on Productivity: The Impact of International Agricultural Research; Centre for Agricultural Bioscience International (CABI): Oxon, UK, 2003.

16. CGIAR. Genetic Improvement. Available online: http://impact.cgiar.org/genetic-improvement (accessed on 1 August 2013).

17. Byerlee, D.; Traxler, G. National and international wheat improvement research in the post-green revolution period: Evolution and impact. Am. J. Agric. Econ. 1995, 77, 268-278.

18. Johnson, N.; Pachico, D.; Voysest, O. The distribution of benefits from public international germplasm banks: The case of beans in Latin America. Agric. Econ. 2003, 29, 277-286.

19. Bellon, M.R.; Adato, M.; Becerril, J.; Mindek, D. The Impact of Improved Maize Germplasm on Poverty Alleviation: The Case of Tuxpeño-Derived Material in Mexico; International Food Policy Research Institute (IFPRI): Washingotn, DC, USA, 2003.

20. Mazid, A.; Amegbeto, K.N.; Keser, M.; Morgounov, A. Adoption and Impacts of Improved Winter and Spring Wheat Varieties in Turkey; International Center for Agricultural Research in the Dry Areas (ICARDA): Aleppo, Syria, 2009.

21. Beyene, H.; Verkuijl, H.; Mwangi, W. Farmers' Seed Sources and Management of Bread Wheat in Wolmera Woreda; International Center for Maize and Wheat Improvement (CIMMYT): Mexico D.F., Mexico, 1998.

22. Manyong, V.M.; Kling, J.G.; Makinde, K.O.; Ajala, S.O.; Menkir, A. Impact of IITA-Improved Germplasm on Maize Production in West and Central Africa; International Institute of Tropical Agriculture (IITA): Ibadan, Nigeria, 2000.

23. Alumira, J.; Rusike, J. The green revolution in Zimbabwe. J. Agric. Dev. Econ. 2005, 2, 50-66.

24. Janaiah, A.; Hossain, M.; Tsuka, K. Productivity mpact of the modern varieties of rice in India. Develop. Econ. 2006, 44, 190-207.

25. Ransom, J. Adoption of improved maize varieties in the hills of Nepal. Agric. Econ. 2003, 29, 299-305.

26. Pandey, S.; Gauchan, D.; Malabayabas, M.; Bool-Emerick, M.; Hardy, B. Patterns of Adoption of Improved Rice Varieties and Farm-Level Impacts in Stress-Prone Rainfed Areas in South Asia; International Rice Research Institute (IRRI): Los Banos, Philippines, 2012.

27. Data exclude exchanges among CGIAR breeding programs.

28. International Wheat Improvement Network Web Page. Available online: http://apps.cimmyt.org/english/wps/obtain_seed/iwin/index.htm (accessed on 1 August 2013).

29. Reynolds, M.P.; Borlaug, N.E. Impacts of breeding on international collaborative wheat improvement. J. Agric. Sci. 2006, 144, 3-17.

30. Wortmann, C.S.; Lunze, L.; Ochwoh, V.A.; Lynch, J. Bean improvement for low fertility soils in Africa. Afr. Crop Sci. J. 1986, 4, 469-476. 
31. Ashby, J.A. The Impact of Participatory Plant Breeding. In Plant Breeding and Farmer Participation; Ceccarelli, S., Guimaraes, E.P., Weltzien, E., Eds.; FAO: Rome, Italy, 2009; pp. 649-671.

32. Biermayr-Jenzano, P.; Garcia, C.X.; Manners, G. Final Report of the PRGA Program (1997-2011); Centro Internacional de Agricultura Tropical (CIAT): Cali, Colombia, 2011.

33. Ceccarelli, S.; Grando, S. Decentralized-participatory plant breeding: An example of demand driven research. Euphytica 2007, 155, 349-360.

34. International Center for Agricultural Research in the Dry Areas. Annual Report; ICARDA: Aleppo, Syria, 2010. Available online: https://apps.icarda.org/wsInternet/wsInternet.asmx/ DownloadFileToLocal?filePath=Annual_report/ICARDA_2010.pdf\&fileName=ICARDA_2010.pdf (accessed on 1 August 2013).

35. Al-Yassin, A. Jordan: In Search of New Benefit-Sharing Practices Through Participatory Plant Breeding. In The Custodians of Biodiversity: Sharing Access to and Benefits of Genetic Resources; Ruiz, M., Vernooy, R., Eds.; Earthscan: Abingdon, UK; International Development Research Centre of Canada (IDRC): Ottawa, Canada, 2012; pp. 67-78.

36. Danial, D.; Parlevliet, J.; Almekinders, C.; Thiele, G. Farmers' participation and breeding for durable disease resistance in the Andean region. Euphytica 2006, 153, 385-396.

37. Gibson, R.W.; Mpembe, I.; Mwanga, R.O.M. Benefits of participatory plant breeding (PPB) as exemplified by the first-ever officially released PPB-bred sweet potato cultivar. J. Agric. Sci. 2011, 149, 625-632.

38. Paris, T.; Singh, A.; Cueno, A.; Singh, V.N. Assessing the impact of participatory research in rice breeding on women farmer: A case study of in eastern Uttarpradesh, India. Exp. Agric. 2008, 44, 97-112.

39. Paris, T.; Manzanilla, D.; Tatlonghari, G.; Labios, R.; Cuneo, A.; Villanueva, D. Guide to Participatory Varietal Selection for Submergence-Tolerant Rice; International Rice Research Institute (IRRI): Manila, Philippines, 2011.

40. IRRI Web Page. The CURE Approach. Available online: http://www.irri.org/index.php? option=com_k2\&view=item\&id=10361\&Itemid=100575\&lang=en (accessed on 26 May 2013).

41. Ntare, B.R. Revitalization of groundnut production in West and Central Africa: Partnership between ICRISAT, the CFC, FAO, NARS and CIRAD. Int. Arachis Newsl. 2003, 23, 12-16.

42. Ntare, B.R.; Ndjeunga, J.; Waliyar, F.; Kodio, O.; Echekwu, C.A.; Kapran, I.; Bissal, H.Y.; Sako, K.; Diallo, A.T.; Da Sylva, A.; et al. Farmer Participatory Evaluation and Dissemination of Improved Groundnut Varieties in West Africa; International Crops Research Institute for the Semi-Arid Tropics: Andra Pradesh, India, 2008.

43. Louwaars, N.; Tripp, R.; Eaton, D.; Henson-Apollonio, V.; Hu, R.; Mendoza, M.; Muhhuku, F.; Pal, S.; Wekundah, J. Impacts of Strengthened Intellectual Property Rights Regimes on the Plant Breeding Industry in Developing Countries: A Synthesis of Five Case Studies; Wageningen UR: Wageningen, The Netherlands, 2005.

44. Ramaswami, B. Understanding the Seed Industry: Contemporary Trends and Analytical Issues; Indian Statistical Institute: New Delhi, India, 2002.

45. Mula, R.P.; Rai, K.N.; Kulkarni, V.N.; Singh, A.K. Public-private partnership and impact of ICRISAT's pearl millet hybrid parents research. J. SAT Agric. Res. 2007, 5, 1-5. 
46. Biggs, S. A multiple source of innovation model of agricultural research and technology promotion. World Dev. 1990, 18, 1481-1499.

47. Rogers, E.M. Diffusion of Innovations, 5th ed.; Free Press: New York, NY, USA, 2003.

48. Leeuwis, C. Communication for Rural Innovation: Rethinking Agricultural Extension; Wiley-Blackwell: Oxford, UK, 2004.

49. Snapp, S.; Kanyama-Phiri, G.; Kamanga, B.; Gilberts, R.; Wellard, K. Farmer and researcher partnerships in Malawi: Developing soil fertility technologies for the near-term and far-term. Exp. Agric. 2002, 38, 411-431.

50. Sechrest, L.; Stewart, M.; Stickle, T. Factors Affecting the Adoption and Impact of CGIAR Innovations: A Synthesis of Findings; A report to the Impact Assessment and Evaluation Group (IAEG); Consultative Group on International Agricultural Research (CGIAR): Washington, DC, USA, 1998.

51. Tripp, R. The Impacts of Food Legume Research in the CGIAR: A Scoping Study; Consultative Group on International Agricultural Research (CGIAR): Washington, DC, USA, 2011.

52. Gollin, D.; Morris, M.L.; Byerlee, D. Technology adoption in intensive post-Green Revolution systems. Agric. Econ. 2005, 87, 1310-1316.

53. Smale, M.; Phiri, A.; Chikafa, G.A.; Heisey, P.W.; Mahatta, F. Institutional Change and Discontinuities in Farmers' Use of Hybrid Maize Seed and Fertilizer in Malawi: Findings from the 1996-1997 CIMMYT/MoLD Survey; International Center for Maize and Wheat Improvement (CIMMYT): Mexico D.F., Mexico, 1996.

54. Doss, C.R. Analyzing technology adoption using microstudies: Limitations, challenges, and opportunities for improvement. Agric. Econ. 2006, 34, 207-219.

55. Chilver, A. The Influence of Institutional Context on the Diffusion of Innovations: Some Lesson from Tru Potato Seed (TPS) in Indonesia. In Into Action Research: Partnership in Asian Rootcrop Research and Development, User's Perspective with Agricultural Research and Development; UPWARD: Los Banos, Philippines, 1996; pp. 227-239.

56. A Strategy and Results Framework for the CGIAR; CGIAR: Washington, DC, USA, 2011.

57. Bantilan, M.C.S.; Deb, U.K.; Gowda, C.L.L.; Reddy, B.V.S.; Obilana, A.B.; Evenson, R.E. Sorghum Genetic Enhancement: Research Process, Dissemination and Impacts; International Crop Research Institute for the Semi-Arid Tropics (ICRISAT): Hyderabad, India, 2004.

58. Deshmukh, S.N.; Satpute, G.N.; Dabre, W.M.; Deshmukh, R.G. PDKV method of own seed production of groundnut. Int. Arachis Newsl. 2001, 21, 23-24.

59. Andrade Piedra, J.L.; Hidalgo, O.A.; Manrique, K.; Velasco, C.; Devaux, A. Diagnostic of Seed Potato Systems in Bolivia, Ecuador and Peru Focusing on Native Varieties. In Tropical Roots and Tubers in a Changing Climate: A Critical Opportunity for the World; International Potato Center (CIP), International Society for Tuber and Root Crops (ISTRC), Universidad Nacional Agraria La Molina (UNALM): Lima, Peru, 2009.

60. Aw-Hassan, A.; Mazid, A.; Salahieh, H. The role of informal farmer-to-farmer seed distribution in diffusion of new barley varieties in Syria. Exp. Agric. 2008, 44, 413-431.

61. MasAgro Home Page. Available online: http://masagro.mx/index.php/es/ (accessed on 26 May 2013). 
62. Secretaría de Agricultura, Ganadería, Desarrollo Rural, Pesca y Alimentación de México (SAGARPA) y Centro Internacional para la Mejora del Maíz y el Trigo (CIMMYT). MasAgro. Program Activities Report 2011-2012; CIMMYT: Mexico D.F., Mexico, 2012. Available online: http://masagro.mx/index.php/en/2012-06-21-17-47-58/documentos/doc_download/15-masagroinforme-de-actividades-2011-2012\#infacte2012 (accessed on 1 August 2013).

63. IRRI Web Page. STRASA: Stress-Tolerant Rice for Africa and South Asia (Phase 2). Available online: http://irri.org/index.php?option=com_k2\&view=itemlist\&task=category\&id=184\&Itemid= 100030 (accessed on 26 May 2013).

64. Patiño, B.O.; Best, R. Strategic alliances of cassava farmers with private and public sectors: A new approach for development of the cassava crop in Latin America. JIRCAS Int. Symp. Ser. 2002, 11, 62-68.

65. Fondo Latinoamericano para Arroz de Riego (FLAR) Home Page. Available online: http://www.flar.org/ (accessed on 26 May 2013).

66. Rubyogo, J.C.; Sperling, L.; Muthoni, R.; Buruchara, R. Bean seed delivery for small farmers in Sub-Saharan Africa: The power of partnerships. Soc. Nat. Resour. 2010, 23, 285-302.

67. Rubyogo, J.C.; Sperling, L.; Nasirumbi, L.; Kasambala, S. Developing Seed Systems with and for the Marginalized: Case of Common Beans (Phaseolus vulgaris L.) in East, Central and Southern Africa. In Proceedings of Farmer First Revisited Conference, Sussex, UK, 12-14 December 2007; Institute of Development Studies (IDS): Sussex, UK, 2007.

68. CGIAR Science Council. CGIAR Center Collaboration: Report of a Survey; CGIAR: Rome, Italy, 2006.

69. Reddy, K.G.; Rao, P.P.; Reddy, B.V.S. Enhancing technology generation and transfer through coalition approach: A case of sorghum poultry coalition, Andhra Pradesh, India. Int. J. Technol. Manag. Sustain. Dev. 2006, 5, 147-157.

70. Spielman, D.J.; Hartwich, F.; von Grebmer, K. Sharing Science, Building Bridges, and Enhancing Impact; International Food Policy Research Institute (IFPRI): Washington, DC, USA, 2007.

71. Gowda, C.L.L.; Reddy, B.V.S. Collaboration with the seed industry in Asia. Asian Seed Plant. Mater. 2004, 11, 38.

72. The CGIAR at 31; World Bank: Washington, DC, USA, 2004.

73. Ayele, S.; Chataway, J.; Wield, D. Partnerships in African crop biotech. Nat. Biotechnol. 2006, 24, 619-621.

74. Agreement on Trade Related Aspects of Intellectual Property Rights, Annex 1C of the Marrakech Agreement Establishing the World Trade Organization, 15 April 1994, 33 ILM 15. Available online: http://www.wto.org/english/tratop_e/trips_e/t_agm0_e.htm (accessed on 1 August 2013).

75. Lopez-Noriega, I.; Wambugu, P.; Mejías, A. Assessment of Progress to Make the Multilateral System Functional: Incentives and Challenges at the Country Level. In Crop Genetic Resources as a Global Commons: Challenges in International Law and Governance; Halewood, M., Lopez-Noriega, I., Louafi, S., Eds.; Routledge: London, UK, 2013.

76. Chiarolla, C.; Jungcurt, S. Outstanding Issues on Access and Benefit Sharing under the Multilateral System of the International Treaty on Plant Genetic Resources for Food and Agriculture; Bern Declaration: Zurich, Switzerland; Development Fund: Oslo, Norway, 2011. 
77. Vernooy, R.; Ruiz, M. Conclusions: Race to the Bottom versus Slow Walk to the Top. In The Custodians of Biodiversity: Sharing Access to and Benefits of Genetic Resources; Ruiz, M., Vernooy, R., Eds.; Earthscan: London, UK; International Development Research Center of Canada (IDRC): Ottawa, Canada, 2012; pp. 163-180.

78. International Network for Genetic Evaluation of Rice (INGER) Home Page. Available online: http://seeds.irri.org/inger/ (accessed on 26 March 2013).

79. Khoury, C.; Laliberté, B.; Guarino, L. Trends in ex situ conservation of plant genetic resources: A review of global crop and regional conservation strategies. Genet. Resour. Crop Evol. 2010, $57,625-639$.

80. The Second Report on the State of the World's Plant Genetic Resources for Food and Agriculture; FAO: Rome, Italy, 2010.

81. Generation Challenge Programme Home Page. Available online: http://www.generationcp.org/ (accessed on 26 May 2013).

82. Aoki, K. Malthus, mendel and monsanto: Intellectual property and the law and politics of global food supply: An introduction. J. Environ. Law Litig. 2004, 19, 397-426.

83. Lamola, L.M. Plant Intellectual Property, the Seed Industry and Technology Transfer; Agricultural Law Centre, Drake University Law School: Des Moines, IA, USA, 1992.

84. Maskus, K.E.; Reichman, J.H. The globalization of private knowledge and the privatization of global public goods. J. Int. Econ. Law 2004, 7, 279-320.

85. Mooney, P.R. Seeds of the Earth: A Private or Public Resource? Food First Books: Oakland, CA, USA, 1979.

86. Primo Braga, C.A. The economics of intellectual property rights and the GATT: A view from the South. Vanderbilt J. Trans. Law 1989, 22, 243-257.

87. Koo, B.; Nottenburg, C.; Pardey, P.G. Plants and intellectual property: An international appraisal. Science 2004, 306, 1295-1297.

88. Lopez-Noriega, I. Defensive Protection of Farmers' Varieties. In Farmers' Varieties and Farmers' Rights: Addressing Challenges in Taxonomy and Law; Halewood, M., Ed.; Earthscan: London, UK, in press.

89. An Act to Amend the Patent and Trademark Laws. Public Law 96-517, 12 Decemember 1980; 96th Congress; 94 STAT. 3015.

90. Kryder, D.; Kowalski, S.; Krattiger, A. The Intellectual and Technical Property Components of Pro-Vitamin A Rice (GoldenRice): A Preliminary Freedom to Operate Review; International Service for the Acquisition of Agri-biotech Applications (ISAAA): Ithaca, NY, USA, 2000.

91. RAFI. Golden Rice and Trojan Trade Reps: A Case Study in the Public Sector's Mismanagement of Intellectual Property; RAFI Communique Issue \#66; RAFI International Office: Winnipeg, Canada, 2000.

92. Neil. New legal decision against Enola bean. CIAT News, 22 July 2009. Available online: http://www.ciatnews.cgiar.org/2009/07/22/new-legal-decision-against-enola-bean/ (accessed on 1 August 2013).

93. In their reports to the Governing Body of the Treaty covering the period 2007-2009 inclusive, only one centre, Bioversity, reported adding any additional terms and conditions to the SMTA when transferring PGRFA under Development (and that was to pass on conditions that had been 
imposed by the depositor of those materials to the international Musa collection). Numerous interviewees confirmed that since that time, some centres have developed terms and conditions which the routinely add to the SMTA when distributing PGRFA under Development.

94. Experience of the International Agricultural Research Centres of the Consultative Group on International Agricultural Research with the Implementation of the Agreements with the Governing Body, with Particular Reference to the Use of the Standard Material; System-wide Genetic Resources Programme (SGRP): Rome, Italy, 2011.

95. Guide for the CGIAR Centres' Use of the Standard Material Transfer Agreement; System-Wide Genetic Resources Programme (SGRP): Rome, Italy, 2010. Available online: http://www.bioversityinternational.org/fileadmin/bioversityDocs/Policy_module/eng.policy_module/ Reference_Material/Guide_SMTA.pdf (accessed on 1 August 2013).

96. CGIAR Web Page. CGIAR Principles on the Management of Intellectual Assets. Available online: http://consortium.cgiar.org/principles-on-management-of-intellectual-assets-approved/ (accessed on 26 May 2013).

97. Experience of the Centres of the Consultative Group on International Agricultural Research (CGIAR) with the Implementation of the Agreements with the Governing Body, with Particular Reference to the Standard Material Transfer Agreement; System-wide Genetic Resources Programme (SGRP): Rome, Italy, 2007.

98. International Treaty on Plant Genetic Resources for Food and Agriculture. Report of the Third Meeting of the Ad Hoc Advisory Technical Committee of the Standard Material Transfer Agreement and the Multilateral System; Food and Agriculture Organization of the United Nations: Rome, Italy, 2012.

99. International Seed Federation. Position Paper on Plant Genetic Resources for Food and Agriculture; adopted in Christchurch, New Zealand, in 2007. Available online: http://www.worldseed.org/cms/medias/file/PositionPapers/OnSustainableAgriculture/PGRFA_20 070523_(En).pdf (accessed on 1 August 2013).

100. CGIAR ADE-PSC. Report of the workshop on Public Private Partnerships and Associated Needs for Product Stewardship and Liability; CGIAR: Washington, DC, USA, 2009.

101. Grain. Africa's seed laws: Red carpet for the corporations. Seedling 2005, July, 28-35.

102. Jarvis, D.I.; Hodgkin, T. The maintenance of crop genetic diversity on farm: Supporting the convention on biological diversity's programme of work on agricultural biodiversity. Biodiversity 2008, 9, 23-28.

103. Bocci, R.; Chable, V. Peasant seeds in Europe: Stakes and prospects. J. Agric. Environ. Int. Dev. 2009, 103, 81-93.

104. Ruiz, M.; Vernooy, R. The Custodians of Biodiversity; Earthscan: London, UK; IDRC: Ottawa, Canada, 2012.

105. Moseley, W.G.; Carney, J.; Becker, L. Neoliberal policy, rural livelihoods and urban food security in West Africa: A comparative study of Gambia, Cote d'Ivoire and Mali. Proc. Natl. Acad. Sci. USA 2010, 107, 5774-5779.

106. Pascual, U.; Perrings, C. Developing incentives and economic mechanisms for in situ conservation in agricultural landscapes. Agric. Ecosyst. Environ. 2007, 121, 256-268.

107. Tripp, R. New Seed and Old Laws; Overseas Development Institute: London, UK, 1997. 
108. Lipper, L.; Anderson, C.L.; Dalton, T.J.; Keleman, A. Conclusions and Policy Implications. In Seed Trade in Rural Markets: Implications for Crop Diversity and Agricultural Development; Lipper, L., Anderson, C.L., Dalton, T.J., Eds.; Food and Agriculture Organization of the United Nations (FAO): Rome, Italy; Earthscan: London, UK, 2010; pp. 209-222.

109. Leskien, D.; Flitner, M. Intellectual Property Rights and Plant Genetic Resources: Options for a Sui Generis System; International Plant Genetic Resources Institute (IPGRI): Rome, Italy, 1997.

110. Louwaars, N. Seed Policy, Legislation and Law: Widening a Narrow Focus; Food Products Press and Haworth Press: Binghamtom, NY, USA, 2002.

111. Kastler, G. Europe's seed laws: Locking out farmers. Seedling 2005, July, 10-16.

112. Manzanilla, D.O.; Paris, T.R.; Vergara, G.V.; Ismail, A.M.; Pandey, S.; Labios, R.V.; Tatlonghari, G.T.; Acda, R.D.; Chi, T.T.N.; Duoangsila, K.; et al. Submergence risks and farmers' preferences: Implications for breeding Sub1 rice in Southeast Asia. Agric. Syst. 2011, 104, 335-347.

113. FAO Seed and Plant Genetic Resource Service. Quality Declared Seed System; FAO Plant Production and Production Paper 117; Food and Agriculture Organization of the United Nations (FAO): Rome, Italy, 1993.

114. FAO Seed and Plant Genetic Resource Service. Quality Declared Seed System; FAO Plant Production and Protection Paper 185; Food and Agriculture Organization of the United Nations (FAO): Rome, Italy, 2006.

115. David, S. Farmer seed enterprises: A sustainable approach to seed delivery? Agric. Human Values 2004, 21, 387-397.

116. David, S.; Kasozi, S.; Wortmann, C. An Investigation of Alternative Bean Seed Marketing Channels in Uganda. Africa; Centro Internacional de Agricultura Tropical (CIAT): Kampala, Uganda, 1997.

117. David, S.; Sperling, L. Improving technology delivery mechanisms: Lessons from bean seed systems research in Eastern and Central Africa. Agric. Human Values 1999, 16, 381-388.

118. Sperling, L.; McGuire, S. Understanding and strengthening informal seed markets. Exp. Agric. 2010, 46, 119-136.

119. Setimela, P.; Monyo, E.; Bänziger, M. Successful Community-Based Seed Production Strategies; CIMMYT: Mexico D.F., Mexico, 2004.

120. Louwaars, N.; Le Coent, P.; Osborn, T. Seed Systems and Plant Genetic Resources for Food and Agriculture: CGRFA Thematic Background Study; FAO: Rome, Italy, 2010.

121. Ellis, F. Agricultural Policies in Developing Countries; Cambridge University Press: Cambridge, $\mathrm{UK}, 1992$.

122. World Development Report: Agriculture for Development; World Bank: Washington, DC, USA, 2008.

123. Lin, J.Y. Hybrid Rice Innovation in China: A Study of Market-Demand Induced Technological Innovation in A Centrally-Planned Economy. Los Angeles; University of California Los Angeles (UCLA): Los Angeles, CA, USA, 1990.

124. Singh, R.P.; Morris, M.L. Adoption, Management and Impact of Hybrid Maize Seed in India; CIMMYT: Mexico D.F., Mexico, 1997.

125. Byerlee, D.; Eicher, C.K. Africa's Emerging Maize Revolution; Lynne Rienner Publishers: Boulder, CO, USA, 1997. 
126. Tripp, R.; Rohrbach, D. Policies for African seed enterprise development. Food Policy 2001, 26, 147-161.

127. Barg, S. Subsidies and Environment: Exploring the Linkages; Organization for Economic Cooperation and Development (OECD): Paris, France, 1996.

128. Di Falco, S.; Perrings, C. Crop biodiversity, risk management and the implications of agricultural assistance. Ecol. Econ. 2005, 55, 459-466.

129. Thrupp, L.A. Linking agricultural biodiversity and food security: The valuable role of agrobiodiversity for sustainable agriculture. Int. Aff. 2000, 76, 283-297.

130. Cororaton, C.B.; Corong, E.L. Philippine Agricultural and Food Policies. Implications for Poverty and Income Distribution; International Food Policy Research Institute (IFPRI): Washingotn, DC, USA, 2009.

131. David, C. Philippine Hybrid Rice Program: A Case for Redesign and Scaling Down; Philippine Institute of Development Studies: Makati City, Philippines, 2007.

132. Bellon, M.R.; Hellin, J. Planting hybrids, keeping landraces: Agricultural modernization and tradition among small-scale maize farmers in Chiapas, Mexico. World Dev. 2010, 39, 1434-1443.

133. Kaur, R.; Sharma, M. Agricultural subsidies in India. Boon or curse. IOSR J. Humanit. Soc. Sci. 2012, 2, 40-46.

134. Sharma, V.P. Food Subsidy in India: Trends, Causes and Policy Reform Options; Indian Institute of Management: Ahmedabad, India, 2012.

135. Nature Editorial. How to feed a hungry world. Nature 2010, 466, 531-532.

136. Yadav, S.S.; Redden, R.; Hatfield, J.L.; Lotze-Campen, H.; Hall, A. Crop Adaptation to Climate Change; John Wiley and Sons: Oxford, UK, 2011.

137. The Second Global Plan of Action for Plant Genetic Resources for Food and Agriculture; FAO: Rome, Italy, 2011.

(C) 2013 by the authors; licensee MDPI, Basel, Switzerland. This article is an open access article distributed under the terms and conditions of the Creative Commons Attribution license (http://creativecommons.org/licenses/by/3.0/). 